Article

\title{
The Selection of Wind Power Project Location in the Southeastern Corridor of Pakistan: A Factor Analysis, AHP, and Fuzzy-TOPSIS Application
}

\author{
Yasir Ahmed Solangi ${ }^{1, *}$, Qingmei Tan ${ }^{1}$, Muhammad Waris Ali Khan ${ }^{2}$, Nayyar Hussain Mirjat ${ }^{3}$ \\ and Ifzal Ahmed 4 \\ 1 College of Economics and Management, Nanjing University of Aeronautics and Astronautics, \\ Nanjing 211106, China; tanchangchina@sina.com \\ 2 Faculty of Industrial Management, University Malaysia, Pahang 26300, Malaysia; waris@ump.edu.my \\ 3 Department of Electrical Engineering, Mehran University of Engineering and Technology, Jamshoro 76062, \\ Pakistan; nayyar.hussain@faculty.muet.edu.pk \\ 4 Department of Business Management, Karakoram International University, Gilgit 15100, Pakistan; \\ ifzal.ahmad@kiu.edu.pk \\ * Correspondence: yasir.solangi86@hotmail.com; Tel.: +86-18651852672
}

Received: 30 May 2018; Accepted: 20 July 2018; Published: 26 July 2018

\begin{abstract}
Pakistan has sufficient wind energy potential across various locations of the country. However, so far, wind energy development has not attained sufficient momentum matching its potential. Amongst various other challenges, the site selection for wind power development has always been a primary concern of the decision-makers. Principally, wind project site selection decisions are driven by various multifaceted criteria. As such, in this study, a robust research framework comprising of factor analysis (FA) of techno-economic and socio-political factors, and a hybrid analytical hierarchy process (AHP) and fuzzy technique for order of preference by similarity to ideal solution (FTOPSIS) have been used for the prioritization of sites in the southeastern region of Pakistan. The results of this study reveal economic and land acquisition as the most significant criteria and sub-criteria, respectively. From the eight different sites considered, Jamshoro has been prioritized as the most suitable location for wind project development followed by Hyderabad, Nooriabad, Gharo, Keti Bandar, Shahbandar, Sajawal, and Talhar. This study provides a comprehensive decision support framework comprising of FA and a hybrid AHP and Fuzzy TOPSIS for the systematic analysis to prioritize suitable sites for the wind project development in Pakistan.
\end{abstract}

Keywords: wind project site selection; factor analysis; AHP; fuzzy TOPSIS; Pakistan

\section{Introduction}

The increased demand for energy across the globe has forced planners and policy-makers to consider the development of non-conventional sources of energy [1]. This consideration is well accompanied with the concern that the World's 7.3 billion population is facing global warming and climate change challenges due to the continuous utilization of conventional energy sources [2]. As such, the harnessing of renewable energy is considered one of the most promising solutions to tackle these challenges. Renewable energy development also ensures energy security for the nations relying on imported resources [3]. In addition, the socio-economic development of nations is also greatly associated with the availability of the various forms of energy. In this context, electricity is one of the most demanded form of energy across various sectors of any economy. However, energy conversion processes for producing electricity are not all coming along smoothly, and instead pose serious challenges pertaining to fuel supplies and containing the emissions. In this context, amongst 
various renewable energy sources used for electricity generation, wind energy is one of the most promising sources of energy [4].

At the moment, Pakistan, on the one hand, is facing a severe energy crisis, while electricity generated from conventional energy sources, mostly imported, are a severe burden on the economy as well adversely affecting the environment [5]. On the other hand, the country is blessed with ample potential for wind energy in the windy regions [6]. In this context, the climatic conditions in the southeastern part of the country are very auspicious for wind energy development. The untapped wind energy potential of this wind corridor can be of great help in meeting electricity demand as well as a source of mitigation of the harmful and toxic gas emissions. The Government of Pakistan (GoP) under Renewable Energy (RE) Policy 2006 has already planned for utilization of renewable energy potential. However, the targets set under this policy have hardly been met so far. The site selection for the development of wind power projects in the wind corridors has also been a key challenge dared by planners and policy-makers.

Amongst other provinces, Sindh province has the highest estimated potential of 88,460 MW electricity which can be produced from wind energy [7]. In this context, alongside the federal government, the provincial government is also encouraging private sector investors to install wind energy projects in the wind corridors of the province. As a result of these efforts, the Gharo and Jhimpir wind corridor are already producing $308 \mathrm{MW}$ electricity, while some other projects of $477 \mathrm{MW}$ capacity are at different stages of project management [8]. In view of the abovementioned facts, this study is an effective step to prioritize the wind project site selection in the wind-rich corridors of the Sindh province.

The highest wind potential in of the Sindh province is reported across eight key regions, namely, Gharo, Nooriabad, Jamshoro, Keti Bandar, Hyderabad, Talhar, Shahbandar, and Sajawal. All these locations have been considered in this study to identify the best of these locations for the wind projects development. The correctly identifying wind project location add significance and help in planning the infrastructure development appropriately.

The installation of a wind power project at suitable locations is a complex decision problem involving techno-economic to socio-political trajectories. It is because that such project development altogether requires huge investment cost, land acquisition, trained manpower and essential infrastructure to commence the project activities. It is also important that geographically project location is feasible and such location is further evaluated on important factors such as economic, technical, environmental, political and social factor [9]. As such, it is very important to systematically prioritize suitable locations before installation of wind power projects to ensure project benefits alongside payback and productivity [10]. The accomplishment of such a task, therefore, requires listing the factors important for the wind project site selection. The detailed factors (sub-criteria) selection must take into account the main criteria recognized in the literature (i.e., economic, environmental, technical, political, and social aspects). Therefore, the detailed factor analysis (FA) in this study follows a system analysis and identification of relevant sub-criteria for each of five main criteria of the study. Further, a hybrid analytical hierarchy process (AHP) and fuzzy technique for order preference by similarity to the ideal solution (FTOPSIS) decision model development and implementation of a wind project site selection in the wind corridors in the southeastern regions (i.e., Sindh province in Pakistan) was accomplished.

It is anticipated that the decision support framework of this study comprising of FA and hybrid AHP, and FTOPSIS shall help planners and policy-makers pertaining to wind project site selection in wind corridors of the Sindh province. There are various instants in the literature wherein multi-criteria decision making (MCDM) methods such as AHP, TOPSIS, and other methods have been used in renewable energy planning [11-13]. However, taking into consideration limited literature on FA, and wind project site selection in the southeastern region of Pakistan, this study will not only aid the literature, but at the same time shall support energy planner and policy-makers appropriately. 
The remaining sections of this study are organized as follows: Section 2 discusses the related work pertaining to wind project installation, site selection, and the key factors which might affect the location of wind projects. Section 3 presents the research framework of the present study. Section 4 describes the results and analysis of the study. Section 5 provides a discussion of the findings of this study and recommendations, followed by the conclusions in Section 6.

\section{Wind Potential in the Southeastern Corridor of Pakistan}

Sindh is the second largest province of Pakistan for its 47-million-person population, and 3rd largest for its area of $140,912 \mathrm{~km}^{2}$. The province is geographically located in the southeast of Pakistan, between the latitudes 26.08 north, and longitudes 66.64 east [14]. Sindh province is blessed with huge renewable energy resources (i.e., solar energy, wind energy, and biomass energy) [15].

The province has ample wind energy potential for electricity generation across the province. The richest of the locations include a coastal line of $60 \mathrm{~km}$ wide and $180 \mathrm{~km}$ long in Gharo, Kati Bander up to Hyderabad with strongest winds recorded around the year [16]. The different locations of this wind corridor include Gharo, Nooriabad, Jamshoro, Keti Bandar, Hyderabad, Talhar, Shahbandar, and Sajawal as shown in Figure 1.

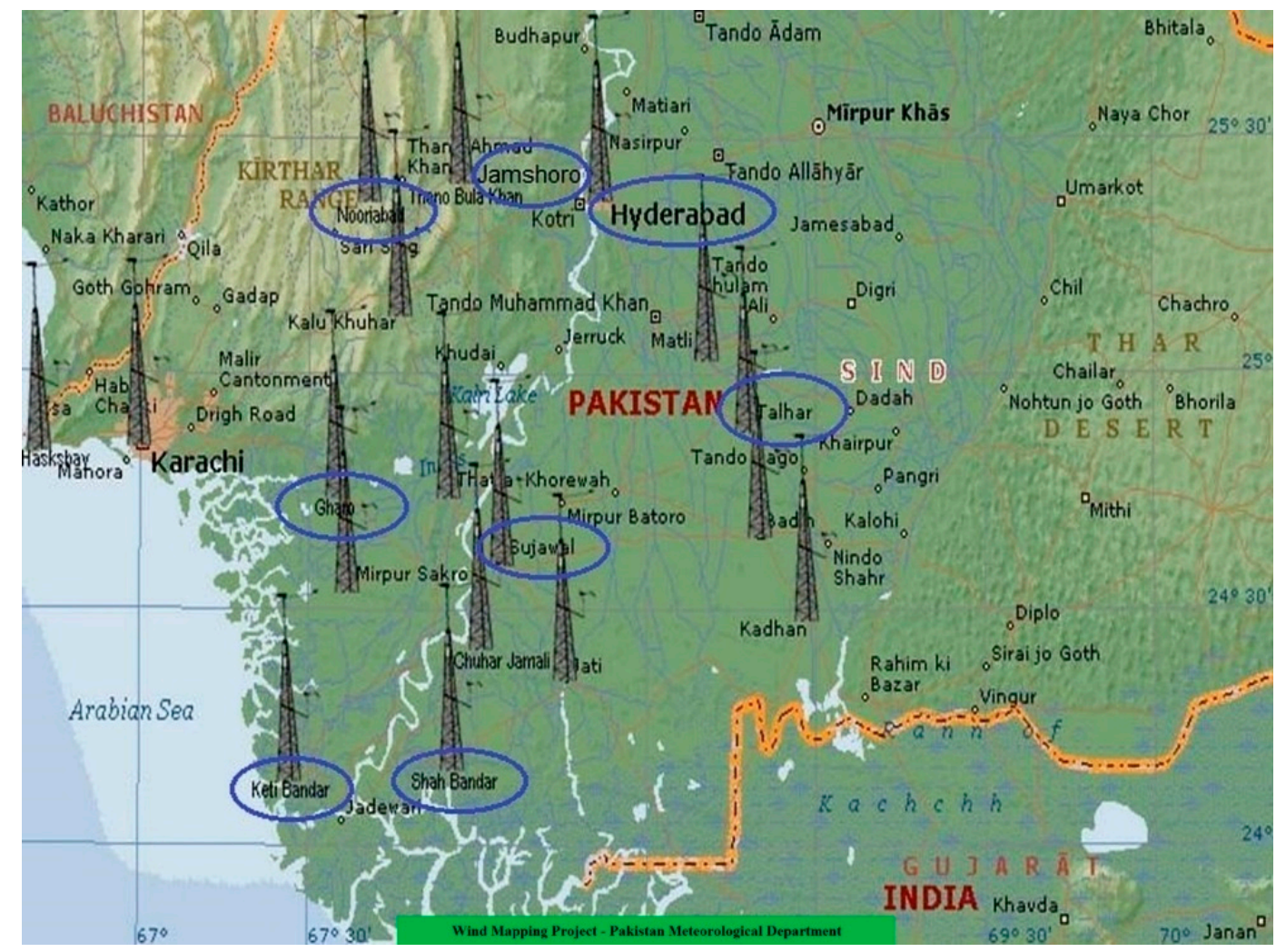

Figure 1. Selected windy regions of Sindh province for the present study [17].

The geographical characteristics of these locations considered in this study are provided in Table 1. 
Table 1. The geographical characteristics of eight cities in Sindh province [18].

\begin{tabular}{ccc}
\hline Name of Region & Longitude & Latitude \\
\hline Gharo & $67.585 \mathrm{E}$ & $24.742 \mathrm{~N}$ \\
Nooriabad & $68.525 \mathrm{E}$ & $25.894 \mathrm{~N}$ \\
Jamshoro & $68.263 \mathrm{E}$ & $25.433 \mathrm{~N}$ \\
Keti bandar & $67.276 \mathrm{E}$ & $24.941 \mathrm{~N}$ \\
Hyderabad & $68.367 \mathrm{E}$ & $25.367 \mathrm{~N}$ \\
Talhar & $68.816 \mathrm{E}$ & $24.883 \mathrm{~N}$ \\
Shahbandar & $67.903 \mathrm{E}$ & $24.165 \mathrm{~N}$ \\
Sajawal & $68.071 \mathrm{E}$ & $24.606 \mathrm{~N}$ \\
\hline
\end{tabular}

It is estimated that around $12.55 \%$ of these selected locations land fall into the moderate to excellent wind power class, with a wind power generation capacity assessment of $88,460 \mathrm{MW}$ as detailed in Table 2.

Table 2. Wind resource potential of the selected regions for electricity generation [7].

\begin{tabular}{ccccc}
\hline $\begin{array}{c}\text { Wind } \\
\text { Class }\end{array}$ & $\begin{array}{c}\text { Potential } \\
\text { Class }\end{array}$ & $\begin{array}{c}\text { Wind Potential } \\
(\mathbf{M W})\end{array}$ & $\begin{array}{c}\text { Land Area } \\
\left(\mathbf{k m}^{\mathbf{2}}\right)\end{array}$ & $\begin{array}{c}\text { Total Wind in the } \\
\text { Selected Region (\%) }\end{array}$ \\
\hline 3 & Moderate & 61,745 & 12,349 & 8.76 \\
4 & Good & 23,200 & 4640 & 3.29 \\
5 & Excellent & 3515 & 703 & 0.50 \\
6 & Excellent & $\mathrm{N} / \mathrm{A}$ & $\mathrm{N} / \mathrm{A}$ & $\mathrm{N} / \mathrm{A}$ \\
7 & Excellent & $\mathrm{N} / \mathrm{A}$ & $\mathrm{N} / \mathrm{A}$ & $\mathrm{N} / \mathrm{A}$ \\
\hline & Total & 88,460 & 17,692 & 12.55 \\
\hline
\end{tabular}

The Alternative Energy Development Board (AEDB) has already approved around 20 wind power projects across these wind corridors. All of these projects' capacities are to be developed by private sector independent power producers (IPPs) in the range of $50 \mathrm{MW}$, which would only bring a mere contribution from a huge cumulative potential of these areas [19]. However, in most of the cases, these projects are facing one or other barriers pertaining from site selection and land acquisition to sovereign guarantee of the investments.

\section{Meteorological Data of the Selected Locations}

The consideration of meteorological data pertaining to the wind energy locations is very important to ascertain the feasibility to develop the wind power plants. According to the international standards of wind power classification, the wind class of the region is central to decision making for the installation of wind projects. These wind power classifications are given in Table 3.

Table 3. International wind power classification at $10 \mathrm{~m}, 30 \mathrm{~m}$, and $50 \mathrm{~m}$ heights [20].

\begin{tabular}{cccccccc}
\hline Class & Potential Class & \multicolumn{3}{c}{ Average Wind Speed $\mathbf{( m / s )}$} & \multicolumn{3}{c}{ Average Wind Power Density $\left(\mathbf{w} / \mathbf{m}^{\mathbf{2}}\right)$} \\
\hline & & $\mathbf{1 0} \mathbf{~ m}$ & $\mathbf{3 0} \mathbf{~}$ & $\mathbf{5 0 ~} \mathbf{~}$ & $\mathbf{1 0} \mathbf{~ m}$ & $\mathbf{3 0} \mathbf{~ m}$ & $\mathbf{5 0} \mathbf{~ m}$ \\
\hline 1 & Poor & $0-4.4$ & $0-5.1$ & $0-5.4$ & $0-100$ & $0-160$ & $0-200$ \\
2 & Marginal & $4.4-5.1$ & $5.1-5.9$ & $5.4-6.2$ & $100-150$ & $160-240$ & $200-300$ \\
3 & Moderate & $5.1-5.6$ & $5.9-6.5$ & $6.2-6.9$ & $150-200$ & $240-320$ & $300-400$ \\
4 & Good & $5.6-6.0$ & $6.5-7.0$ & $6.9-7.4$ & $200-250$ & $320-400$ & $400-500$ \\
5 & Excellent & $6.0-6.4$ & $7.0-7.4$ & $7.4-7.8$ & $250-300$ & $400-480$ & $500-600$ \\
6 & Excellent & $6.4-7.0$ & $7.4-8.2$ & $7.8-8.6$ & $300-400$ & $480-640$ & $600-800$ \\
7 & Excellent & $>7$ & $8.2-11$ & $>8.6$ & $>400$ & $640-1600$ & $>800$ \\
\hline
\end{tabular}


As per these international standards, the following two factors are essentially vital and should be considered well before choosing or selecting a site for wind tower installation [21]: (a) The selected region must be windy and cover all of the parts of the region as per relevant wind power classification. (b) The towers should be installed far away from each other so that they do not cause obstructions to the wind.

The additional consideration regarding wind power site selection is the annual average wind speed $(\mathrm{m} / \mathrm{s})$ and wind power density $\left(\mathrm{w} / \mathrm{m}^{2}\right)$. The parameters for the eight selected locations of this study are given in Table 4 .

Table 4. Average wind speed and power density at $10 \mathrm{~m}, 30 \mathrm{~m}$, and $50 \mathrm{~m}$ heights in selected regions of the southeastern corridor of Pakistan [17].

\begin{tabular}{cccccccc}
\hline No. & Selected Regions & \multicolumn{3}{c}{ Average Wind Speed $\mathbf{( m / s )}$} & \multicolumn{3}{c}{ Average Wind Power Density $\left(\mathbf{w} / \mathbf{m}^{\mathbf{2}}\right)$} \\
\hline & & $\mathbf{1 0} \mathbf{~ m}$ & $\mathbf{3 0} \mathbf{~ m}$ & $\mathbf{5 0 ~} \mathbf{~}$ & $\mathbf{1 0 ~} \mathbf{~}$ & $\mathbf{3 0 ~} \mathbf{~}$ & $\mathbf{5 0} \mathbf{~ m}$ \\
\hline L1 & Gharo & 3.6 & 5.6 & 6.6 & 110 & 233 & 360 \\
L2 & Nooriabad & 5.0 & 6.2 & 7.0 & 221 & 361 & 454 \\
L3 & Jamshoro & 4.2 & 6.9 & 8.5 & 160 & 424 & 771 \\
L4 & Ketibandar & 4.6 & 6.1 & 7.0 & 163 & 281 & 396 \\
L5 & Hyderabad & 3.8 & 5.5 & 6.4 & 123 & 264 & 372 \\
L6 & Talhar & 1.4 & 4.5 & 6.2 & 24 & 147 & 445 \\
L7 & Shahbandar & 4.2 & 5.5 & 6.2 & 108 & 174 & 247 \\
L8 & Sajawal & 2.4 & 5.0 & 6.4 & 34 & 146 & 299 \\
\hline
\end{tabular}

It is evident that all the regions considered in this study have enough wind resource potential to develop wind power projects. Therefore, a detailed investigation in this study has been undertaken to prioritize these locations systematically.

\section{Research Framework}

The complex trajectories involved in the selection of a site for the wind power plants, elaborated in an earlier section of the paper, require careful consideration and development of an appropriate scientific decision framework. Therefore, in this study, a comprehensive research framework comprising of FA, hybrid AHP, and a fuzzy TOPSIS decision model has been developed, as shown in Figure 2.

In the implementation of this framework, the economic, environmental, technical, political, and social (EETPS) factors affecting the site selection of wind projects in the context of Pakistan have been identified using FA, which is processed based on literature review and experts' recommendations. This is followed by the establishment of a decision hierarchy of economic, environmental, technical, political and social (EETPS) criteria and sub-criteria using the AHP method. Experts were consulted again to check for errors or if a high inconsistency $(>10 \%)$ was found in the AHP results. Finally, based on the criteria weighs determined in the AHP methodology, the Fuzzy TOPSIS method was used to firmly prioritize the different locations considered in this study for development of the wind projects.

The summary description of each methodology of the proposed research framework of this study is given below. 


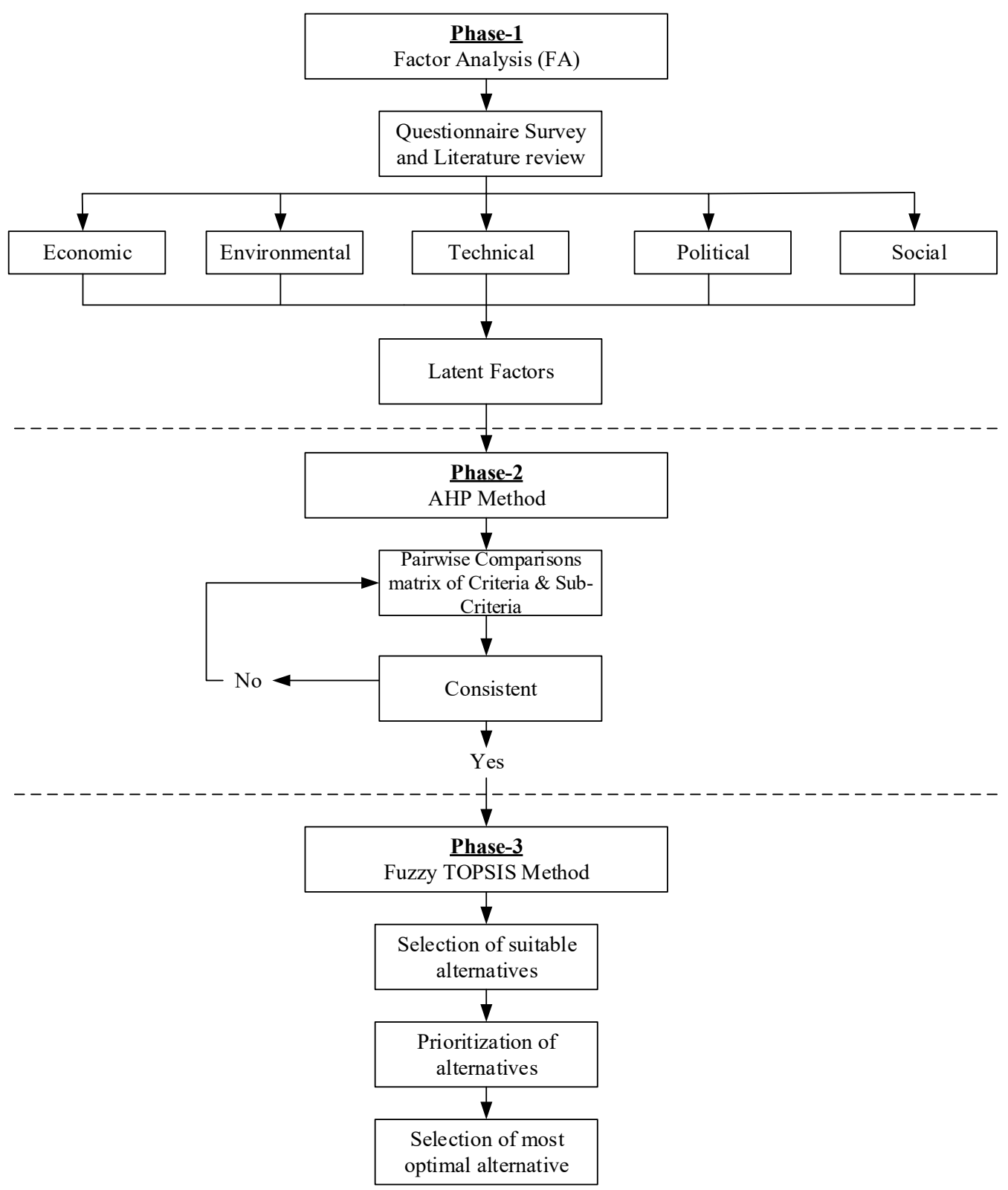

Figure 2. The research framework of the study.

\subsection{Factor Analysis (FA)}

The factor analysis technique was developed by Charles Spearman [22]. Factor analysis is a statistical technique which is used to reduce a large number of variables into small numbers of factors. The FA method extracts maximum variance from all the variables and put them into a common score. There are several types of factoring methods which are used to extract the factors from the data sets. In the factor analysis, the factor loading is commonly the correlation coefficient of the variables and factors [23]. The factor loading shows the variance explained by the variable on that specific factor, whereas, eigenvalue provides variance explained by that particular factor out of the total variance. Subsequently, the factor score is determined, which is also called the component score. Factor score is the sum of all row and columns, which can be used as an index of all variables and can be used for further analysis.

According to Reference [24], Kaiser criterion and eigenvalues are good criteria for determining a factor. As such, if the eigenvalue of a factor is greater than 1 , it can be considered, and if less than 1 , then 
it may not be considered. Further, in the FA, the rotation method makes it more reliable to understand the output. The eigenvalue cannot affect the rotation method. However, the rotation method affects the eigenvalue or percentage of variance extracted. There are several numbers of rotation methods, such as varimax rotation, no rotation, promax rotation, quartimax rotation, and direct oblimin rotation method. However, in this study, we have applied the varimax rotation method to refine the factors.

In the process of FA, this study has identified five main criteria namely economic, technical, environmental, political, and social factors. The importance and relevance of these factors pertaining to this study are discussed in the following section which is followed by detailed sub-criteria identification based on the FA process in the subsequent section.

\subsubsection{Importance of Economic, Technical, Environmental, Political, and Social Factors}

The economic, technical, environmental, political, and social factors, which are taken as the main criteria in this study, are very relevant and identified from the literature [25]. Pakistan is a developing country, and all these factors are very relative to any major project development endeavour. However, these factors although considered in the decision-making process, are not often systematically analyzed for decision alternatives. As such, the quality of decisions are inferior, and judgement defense is very poor. Further, the related work pertaining to the development of wind projects considering these factors is evident in the literature. Latinopoulos and Kechagia [26] used GIS-based, multi-criteria assessment for wind project location selection in Greece; they considered economic, technological, social, and environmental factors as criteria with substantial numbers of sub-criteria. Azizi et al. [27] used the environmental, technical, and economic factors in wind power plant site selection. Al-Yahyai et al. [28] have also considered various dimensions to evaluate the suitability of land for wind projects site selection in Oman, including the distance to roads, slope, historical locations, nature, wind power, and energy demand. Tegou LI et al. [29] have considered four criteria (i.e., economic, technical, environmental, and social) in the selection of potential locations for wind power projects on the island of Lesvos, Greece. They also assessed the wind project site selection based on other factors, such as land cover, visual impact, wind resources, land value, and distance from the power station. Ljubomir and others [30] have listed eleven criteria for selecting suitable locations for wind projects in Serbia, these were wind speed, land use, distance from urban areas, distance from protected areas, distance from power lines, slope of the land, distance from roads, aspects, distance from telecommunication infrastructure, distance from tourist facilities, and population density. In addition, Noorollahi et al. [31] considered economic, technical, environmental, and geographic as key factors for the wind power project site selection. Based on this study, they recommended that wind energy is an economical option for improving the economic conditions of Iran.

Mazhar Hussain et al. [20] have presented a technical proposal for off-grid electricity generation from six wind sites of two provinces in Pakistan. In the meantime, Yousaf Ali et al. [32] have only identified six key criteria (i.e., wind speed, wind power density, capacity factor, transport cost, distance from grid station, and population density) for wind project site selection, but have not implemented these criteria. Pamučar et al. [33] have investigated suitable locations for wind projects installation in Serbia with seven main criteria namely, wind speed average, land cover/use, distance from main communication, slope, orientation aspect, distance from urban places, and distance from power lines. Yeh and Huang [34] have also investigated various key factors in determining wind project location, and these include safety and quality, economy and benefits, social impression, environment and ecology, and policy. Watróbski et al. [35] used AHP and preference ranking organization method for enrichment of evaluations (PROMETHEE) in carrying out a feasibility study of selecting wind farm location in Szczecin city of Poland. Another study by Watróbski et al. [36] has defined the methodological aspects of a decision support system for localizing offshore wind farms. Wu et al. [37] have developed a decision-making framework for the selection of offshore wind sites using Elimination et Choix Traduisant la Realité-III (ELECTRE-III). Sanchez et al. [38] combined fuzzy approaches of different Multi-Criteria Decision Making (MCDM) to deal with the current decision problem of onshore 
wind site selection. Therefore, in this study, we have considered the main criteria and sub-criteria for the selection of wind power projects located in the southeastern corridor of Pakistan. These criteria and sub-criteria are given in Table 5.

Table 5. List of main criteria and sub-criteria.

\begin{tabular}{ccccc}
\hline Economic Factor & $\begin{array}{c}\text { Environmental } \\
\text { Factor }\end{array}$ & Technical Factor & Political Factor & Social Factor \\
\hline $\begin{array}{c}\text { Development cost } \\
{[39,40]}\end{array}$ & $\begin{array}{c}\text { Public health and } \\
\text { community impact } \\
{[41]}\end{array}$ & $\begin{array}{c}\text { Wind data } \\
\text { availability [27,42] }\end{array}$ & $\begin{array}{c}\text { Government } \\
\text { policies [43] }\end{array}$ & $\begin{array}{c}\text { Effect on economic } \\
\text { development of } \\
\text { nearby areas [31] }\end{array}$ \\
\hline $\begin{array}{c}\text { On-grid } \\
\text { accessibility } \\
{[29-31]}\end{array}$ & $\begin{array}{c}\text { Wildlife and } \\
\text { habitat impact [42] }\end{array}$ & $\begin{array}{c}\text { Climate conditions } \\
{[29]}\end{array}$ & $\begin{array}{c}\text { Land acquisition } \\
{[39,40]}\end{array}$ & $\begin{array}{c}\text { Distance from } \\
\text { residential areas } \\
{[27,30,31]}\end{array}$ \\
\hline $\begin{array}{c}\text { Road availability } \\
{[28-31]}\end{array}$ & $\begin{array}{c}\text { Area of flatland } \\
\text { and without forest } \\
\text { cover [27,29] }\end{array}$ & $\begin{array}{c}\text { Skilled manpower } \\
\text { availability [39,40] }\end{array}$ & $\begin{array}{c}\text { Relocation and } \\
\text { rehabilitation [42] }\end{array}$ & $\begin{array}{c}\text { Effect on } \\
\text { employment and } \\
\text { agriculture [44] }\end{array}$ \\
\hline & & & Social acceptance \\
{$[43]$}
\end{tabular}

In summary, the main criteria considered in this study (i.e., economic, technical, environmental, political, and social factors) are vital aspects of wind power plant development in Pakistan.

\subsubsection{Factor Analysis for Determining the Sub-Criteria}

The selection of sub-criteria for each of the five main criteria has been accomplished in this study using factor analysis. In this process, a small number of underlying factors have been identified to relate each sub-criteria relevance to the main criteria. As such, the factors and their latent items, the extent of variance represented by each extracted factor, have been investigated. The rotated component matrix, variance calculation, and latent factors scoring above 0.50 have been represented. A survey instrument comprising of 16 items with the option to select any one from these for relevant main criteria was provided to the respondent. The five points Likert scale ranging from Strongly Disagree (1) to Strongly Agree (5) was administered to 300 respondents working in government and privately sponsored renewable energy projects in Pakistan. The respondents were given a two-week period for their responses to the questionnaire. During this period, an overall 175 responses were received successfully. After removing invalid and incomplete responses, a total of 150 completed questionnaires were acknowledged and taken into consideration. This gives an overall response rate of $50 \%$. The feedback from the respondents also contained some omissions and missing figures. These response omissions were the source of errors during the analysis. Hence, these problems were appropriately addressed by using the Missing Value Analysis tool of the Statistical Package for the Social Sciences (SPSS). The response of the participants pertaining to the factors and the latent items attributing to the establishment of the key factors affecting the location of wind power projects have been analyzed.

The collected data from these respondents were analyzed using SPSS software to determine the underlying factors, provided in the results section of this paper.

\subsection{Multi-Criteria Decision Making (MCDM) Approach}

The AHP and FTOPSIS methods are two key methodology pillars of this study's research framework. The AHP and TOPSIS methods are the techniques of MCDM methods widely used in energy and environment planning and complex decision analysis [45]. The traditional assessment/analysis methods like environmental impact assessment (EIA), cost-effectiveness analysis (CEA), and cost-benefit analysis (CBA) are limited in nature and scope, and generally do not take care 
of social, risk, and uncertainty factors effectively [46]. Therefore, MCDM methods have found their greater application across various disciplines of engineering, social sciences, governance, and project management [47].

The MCDM comprises a number of research methods. These includes TOPSIS [48], AHP [49], data envelopment analysis (DEA) [50], multi-attribute utility theory (MAUT) [51], multi-attribute value theory (MAVT) [52], preference ranking organization method for enrichment of evaluations (PROMETHEE) [53], measuring attractiveness by a categorical based evaluation technique (MACBETH) [54], multi-objective decision making (MODM), elimination and choice translating reality (ELECTRE), visekriterijumsko kompromisno rangiranje (VIKOR), and decision support systems [55]. In recent literature, PROMETHEE for sustainability assessment (PROSA) has also been used to solving wind energy decision problems [56]. The new easy approach to Fuzzy PROMETHEE (NEAT F-PROMETHEE) has also surfaced recently as an MCDM method based on the adjustment of mapping trapezoidal fuzzy numbers [57]. However, each of these methods has its own strengths and limitations. Nevertheless, the AHP has been the most widely used amongst all the MCDM methods [58]. The AHP has been selected for the present study because it has the ability to convert the multifaceted decision problem into a simple problem. A brief description of AHP methodology is given in the following sub-section, which shall be followed by the summary description of the TOPSIS methodology in the subsequent sub-section.

\subsubsection{Analytical Hierarchy Process (AHP)}

The AHP method was developed by Saaty in the 1970s [59]. It has the ability to convert a complex decision problem into a simple problem in a hierarchical order. In addition to this, the AHP has the capability to use quantitative and qualitative data in one model. Therefore, the AHP method has been selected for this study because of its several irresistible characteristics, such as:

- It helps in managing complex decision problems, and unorganized and multi-characteristic issues.

- It helps decision-makers to evaluate complex problems in a hierarchical order and makes it simple.

- It can be used for both quantitative and qualitative data.

- It organizes in a hierarchical model for solving intricate decision problems.

- It provides consistency during the assessment process.

The procedure in the AHP is explained in the following steps [60].

Step 1 Firstly, construct a decision hierarchy with criteria and goal at the top of the hierarchy.

Step 2 Develop a pairwise comparison matrix of the criteria and sub-criteria with accurate consistency. The pairwise comparison matrix was obtained from experts using a 1-9 point scale, which is illustrated in Table 6 . The matrix was acquired as $(n \times n)$, where $n$ donates the number of criteria.

Step 3 Let $X_{i j}$ denote the preference order of the $i$ th objective as compared to the $j$ th objective. After that, $X_{j i}=\frac{1}{X_{i j}}$.

Step 4 To obtain the normalized pairwise comparison matrix it is important to follow the proper procedures, such as calculating the sum of the column, dividing each matrix by its obtained column sum, and taking the average of the rows to get the relative weights.

Step 5 In this step, the Eigen vector, maximum Eigen value, and consistency index $(C I)$ can be calculated using Equation (1).

$$
C I=\frac{\lambda_{\max }-1}{n-1}
$$

where $\lambda_{\max }$ is the Eigen value and $n$ is the number of criteria.

Step 6 Lastly, the consistency ratio $(C R)$ is calculated using Equation (2).

$$
C R=\frac{C I}{R I}
$$


here, $R I$ is the random index. The value of $R I$ is illustrated in Table 7 . The acceptable range of the $C R$ value is less than 0.1 [61].

Table 6. Saaty pairwise comparison matrix scale [49].

\begin{tabular}{cc}
\hline Numerical Values & Verbal Definition (Comparing Factor $\mathbf{X}$ and $\mathbf{Y})$ \\
\hline 1 & Equally important factors \\
2 & Equally to moderate important \\
3 & Moderate important \\
4 & Moderately to strongly important \\
5 & Strongly important \\
6 & Strongly to very strongly important \\
7 & Very strongly important \\
8 & Very strongly to extremely important \\
9 & Extremely important \\
Reciprocals & Factor X is less important than factor $\mathrm{Y}$ \\
\hline
\end{tabular}

Table 7. Random Index (RI) [16].

\begin{tabular}{cc}
\hline Number & Random Index \\
\hline 1 & 0.00 \\
2 & 0.00 \\
3 & 0.058 \\
4 & 0.90 \\
5 & 1.12 \\
6 & 1.24 \\
7 & 1.32 \\
8 & 1.41 \\
9 & 1.45 \\
10 & 1.49 \\
\hline
\end{tabular}

The accomplishment of AHP steps in this study would provide the weights of the main-criteria and sub-criteria of the study, which would be used in the Fuzzy TOPSIS model to rank the alternatives.

\subsubsection{Fuzzy Technique for Order Preference by Similarity to the Ideal Solution (FTOPSIS)}

The TOPSIS method was proposed by Hwang and Yoon [62]. The ambition of this technique is to identify the maximum and minimum gaps between the ideal and negative solution [63]. Despite the fact that it is a famous technique of MCDM, the method suffers from various drawbacks. In real interpretation, it fails to provide clear information and has undefined and ambiguous issues. A preferable method is to assess the weights and rankings of the criteria using linguistic variables instead of numerical values. Decision-makers are able to gratify incomplete, immeasurable information and partially ignorant facts with the use of the fuzzy sets theory. The triangular fuzzy number (TFN) is most frequently used in MCDM methods to solve these problems. A TFN is a triple $A=\left(a_{Z}, b_{Z}, c_{Z}\right)$ where, $a_{Z}, b_{Z}, c_{Z} \in \mathbb{R}\left(a_{Z} \leq b_{Z} \leq c_{Z}\right)$, with the following membership function form:

$$
\mu A(x)=\left\{\begin{array}{lll}
\frac{x-a_{Z}}{b_{Z}-a_{Z}} & \text { if } & a_{Z} \leq x \leq b_{Z} \\
\frac{c_{Z}-x}{c_{Z}-b_{Z}} & \text { if } & b_{Z} \leq x \leq c_{Z}
\end{array}\right.
$$

The TFN can be used to represent linguistic variables, which can be used for the assessment of alternatives with respect to each criterion. The TFN rating scale often used in MCDM problems is presented in Table 8. 
Table 8. Linguistic variables and Triangular Fuzzy Numbers (TFNs) [64].

\begin{tabular}{ccc}
\hline Number & Linguistic Variables & TFNs \\
\hline 1 & Very Bad & $(1,1,3)$ \\
2 & Bad & $(1,3,5)$ \\
3 & Medium & $(3,5,7)$ \\
4 & Good & $(5,7,9)$ \\
5 & Very Good & $(7,9,9)$ \\
\hline
\end{tabular}

The fuzzy TOPSIS technique based on TFNs can be denoted as in the following steps: where $i=1,2,3, \ldots, m$ and $j=1,2,3, \ldots, n$ :

Step 1 Define the fuzzy decision matrix $X$ :

$$
X=\left(x_{i j}\right)_{m \times n}
$$

where $x_{i j}=\left(a_{i j}, b_{i j}, c_{i j}\right)$.

Step 2 Establish the normalized fuzzy decision matrix $R$ using linear scale normalization.

$$
R=\left[r_{i j}\right]_{m \times n}
$$

here, $i=1,2,3, \ldots, m$ and $j=1,2,3, \ldots, n$.

$$
r_{i j}=\left(\frac{a_{i j}}{c_{j}^{+}}, \frac{b_{i j}}{c_{j}^{+}}, \frac{c_{i j}}{c_{j}^{+}}\right)
$$

where, $c_{j}^{+}=\operatorname{maxc}_{i j}$ (benefit criteria).

$$
r_{i j}=\left(\frac{a_{j}^{-}}{c_{i j}}, \frac{a_{j}^{-}}{b_{i j}}, \frac{a_{j}^{-}}{a_{i j}}\right)
$$

$a_{j}^{-}=\min a_{i j}$ (cost criteria).

Step 3 Calculate the weighted normalized fuzzy decision matrix by utilizing Equation (7).

$$
V=\left[v_{i j}\right]_{m \times n}
$$

here, $v_{i j}=r_{i j} \times w_{j}$.

Step 4 Identify the fuzzy positive ideal solution and fuzzy negative ideal solution.

The fuzzy positive ideal solution:

$$
A^{+}=\left(v_{1}^{+}, v_{2}^{+}, v_{3}^{+}, \ldots, v_{n}^{+}\right)
$$

where, $j=1,2,3, \ldots, n$.

$$
V_{j}^{+}=\max v_{i j} \text { if }(j \in J) \text {; } \min v_{i j} \text { if }\left(j \in J^{\prime}\right)
$$

The fuzzy negative ideal solution:

$$
A^{-}=\left(v_{1}^{-}, v_{2}^{-}, v_{3}^{-}, \ldots, v_{n}^{-}\right)
$$


where, $j=1,2,3, \ldots, n$.

$$
V_{j}^{-}=\max v_{i j} \text { if }(j \in J) ; \min v_{i j} \text { if }\left(j \in J^{\prime}\right)
$$

All these computations are particular to linear normalization [65].

Step 5 Compute the distance of each alternative from the fuzzy $A^{+}$and fuzzy $A^{-}$using Equations (13) and (14).

Fuzzy positive ideal solution $A^{+}$

$$
d_{i}^{+}=\sum_{j=1}^{n} d\left(v_{i j}-v_{j}^{+}\right)
$$

where, $j=1,2,3, \ldots, m$, and fuzzy negative solution $A^{-}$

$$
d_{i}^{-}=\sum_{j=1}^{n} d\left(v_{i j}-v_{j}^{-}\right)
$$

where, $j=1,2,3, \ldots, m$.

Here, the distance between two fuzzy numbers $A=\left(x_{1}, x_{2}, x_{3}\right)$ and $B=\left(y_{1}, y_{2}, y_{3}\right)$

$$
d(A, B)=\sqrt{\frac{1}{3}\left[\left(x_{1}-y_{1}\right)^{2}+\left(x_{2}-y_{2}\right)^{2}+\left(x_{3}-y_{3}\right)^{2}\right]}
$$

Step 6 Compute the closeness coefficient $\left(C C_{i}\right)$ of the alternative to the positive $A^{+}$and negative $A^{-}$ideal solution using Equation (16).

$$
C C_{i}=\frac{d_{i}^{-}}{d_{i}^{+}+d_{i}^{-}}
$$

where, $i=1,2,3, \ldots, m ; d_{i}^{+}$is the distance from the fuzzy positive ideal solution and $d_{i}^{-}$is the distance from the fuzzy negative ideal solution.

Step 7 Rank the alternatives and select the one with the biggest value of $C C_{i}$. The finest alternative is the one having the minimum distance to the fuzzy positive ideal solution and the maximum to the fuzzy negative ideal solution.

The accomplishment of the above steps would provide the ranking of alternatives with distance to highest and least optimal solution.

\subsubsection{The Survey Respondents for AHP and Fuzzy TOPSIS Study}

It is very important to engage qualified and professional experts while applying any MCDM method since the inconsistency of the weights assigned by the experts is always uncertain [66]. Generally, stakeholders, research specialists, interest groups or managers are engaged for weight scoring to analyze the situation and increase the decision power [67]. As such, in this study to maintain the consistency and validity of the study a small number of expert (i.e., five) were engaged as respondents in both AHP and Fuzzy TOPSIS steps of the research framework. The summary of experts' details is shown in Table 9.

With the help of respondents' judgmental scoring, the criteria and sub-criteria weights were determined using the priority ranking of the AHP method. In the next phase, the fuzzy TOPSIS method was used to analyze the selection of a suitable site for wind project development in the southeastern part of Pakistan. 
Table 9. Experts' information.

\begin{tabular}{cc}
\hline Classification & Number of Experts \\
\hline University professor & 2 \\
Energy expert & 1 \\
Economic expert & 1 \\
Stakeholder & 1 \\
\hline
\end{tabular}

\section{Results and Analysis}

\subsection{Factor Analysis Results}

In the factor analysis, the principal factor extraction with a varimax rotation approach was accomplished using the SPSS software as shown in Table 10. The total variance explained by each factor is listed in the column under factor loading. The percentage of variance and the cumulative percentage of the variance for each factor is provided. In total, 16 factors for five main-criteria were analyzed. The first two main criteria factors accounted for $13 \%$ and $12 \%$ of the variance. All the factor loadings have been greater than 0.5 , and to be more particular 12 factors are with more than 0.7 loading factor.

Table 10. Factor structure of principal factors extraction and varimax rotation.

\begin{tabular}{|c|c|c|c|}
\hline Item Number & $\begin{array}{l}\text { Factor } \\
\text { Loading }\end{array}$ & $\begin{array}{l}\% \text { of Variance } \\
\text { Explained }\end{array}$ & $\begin{array}{l}\text { Cumulative \% Age of } \\
\text { Variance Explained }\end{array}$ \\
\hline $\begin{array}{l}\text { Factor 1: Economic Factor (EF) } \\
\text { Development cost (EF1) } \\
\text { On-grid accessibility (EF2) } \\
\text { Road availability (EF3) }\end{array}$ & $\begin{array}{l}0.881 \\
0.854 \\
0.769\end{array}$ & 13.584 & 13.584 \\
\hline $\begin{array}{l}\text { Factor 2: Environmental Factor (EN) } \\
\text { Public health and community impact (EN1) } \\
\text { Wildlife and habitat impact (EN2) } \\
\text { Area of flatland and without forest cover (EN3) }\end{array}$ & $\begin{array}{l}0.822 \\
0.697 \\
0.675\end{array}$ & 12.564 & 26.148 \\
\hline $\begin{array}{l}\text { Factor 3: Technical Factor (TF) } \\
\text { Wind data availability (TF1) } \\
\text { Climate conditions (TF2) } \\
\text { Skilled manpower availability (TF3) }\end{array}$ & $\begin{array}{l}0.854 \\
0.813 \\
0.644\end{array}$ & 9.714 & 35.862 \\
\hline $\begin{array}{l}\text { Factor 4: Political factor (PF) } \\
\text { Government policies (PF1) } \\
\text { Land acquisition (PF2) } \\
\text { Relocation and rehabilitation (PF3) }\end{array}$ & $\begin{array}{l}0.820 \\
0.734 \\
0.627\end{array}$ & 8.889 & 44.751 \\
\hline $\begin{array}{l}\text { Factor 5: Social factor (SF) } \\
\text { Effect on economic development of nearby } \\
\text { areas (SF1) } \\
\text { Distance from residential areas (SF2) } \\
\text { Effect on employment and agriculture (SF3) } \\
\text { Social acceptance (SF4) }\end{array}$ & $\begin{array}{l}0.933 \\
0.796 \\
0.760 \\
0.734\end{array}$ & 9.934 & 54.685 \\
\hline
\end{tabular}

Each of these factors are very important for the site selection for the wind power projects and are briefly defined as follows.

\subsubsection{Economic Factor (EF)}

The economic aspect of wind turbine installation at a particular area or region relies on grid and transmission availability, wind resource, and distance from roads [68]. In developing countries, 
investment cost is higher than the developed countries due to several reasons, such as poor existing infrastructure, unskilled labour, and bringing engineers from foreign countries.

Development Cost (EF1)

The electricity generation from wind requires a well-developed infrastructure system for transmission line accessibility, road facilities, water supply, and some other local infrastructure in the region to transfer the electricity to the end user. A supplementary electricity generation capacity must be available for the times when the renewable energy (RE) resources abruptly cease to generate electricity [69].

\section{On-Grid Accessibility (EF2)}

The on-grid accessibility of transmission lines near to the power project is very important from economic aspects. The location of the wind plant must be within $2000 \mathrm{~m}$ of the electricity grid otherwise it may be considered as not economically feasible [29].

\section{Road Availability (EF3)}

Distance from roads can provide a lower construction cost in the project. It is suggested that suitable sites must be at a minimum distance and should not exceed $10 \mathrm{~km}$ from the roads [70]. Thus, the selected location must be only a short distance from the road.

\subsubsection{Environmental Factor (EN)}

The wind project location selection must also consider the environmental aspects, such as public health and community, wildlife and habitat, and land use impact.

Impact on Public Health and Community (EN1)

Visual and noise impacts are the two main public health and community concerns linked with operating wind turbines in the area. Due to the higher degree of noise from wind turbines, the people living near to these projects have complained about these issues, but it has been found that noise and visual impacts do not have any direct negative impact on public health [71].

Impact on Wildlife and Habitat (EN2)

The wind turbines have a direct impact on wildlife, most particularly on birds, which has been widely studied and documented. Various studies have found evidence of bird deaths due to changes in air pressure caused by the spinning turbines and from collisions with the wind turbines, also from habitat disruption [72]. These impacts do not pose a threat to species populations as their impacts are comparatively low.

\section{Area of Flatland and without Forest Cover (EN3)}

The land requirement of wind power depends on the site, the wind turbines placed in flat areas use more land than those located in hilly regions, although wind turbines do not take up all of the land. From the survey report of the National Renewable Energy Laboratory, NREL, it was found that the wind project land can also be utilized for some other purposes, including agriculture, livestock grazing, and highways [73]. Thus, the area which has flat land is very useful because the wind is not obstructed by dense forests.

\subsubsection{Technical Factor (TF)}

Before establishing the wind site selection, the various uncertainties and scientific issues must be addressed and require due consideration. 
Wind Data Availability (TF1)

It is very important to obtain accurate wind data before setting up a wind power plant. The wind site must be selected after getting proper sufficient and available data, such as the wind power speed and wind power density of the selected location [74].

Skilled Manpower Availability (TF2)

Availability of skilled manpower is required to install, maintain, coordinate, and monitor the operation of the wind power plants [75]. If the people are capable in the region, it will be very useful. Alternatively, training may be provided to the people who can operate the wind power plant, but it adds to the extra cost.

Climate Conditions (TF3)

The performance of a wind power system depends on the weather conditions at the site, such as low air pressure, because a wind generator requires at least $3 \mathrm{~m} / \mathrm{s}$ wind speed or above [76]. In addition, it must be in an area with a minimum chance of sudden disasters like powerful bursts of wind and floods which affect the performance of wind turbines [77]. Therefore, it is very important to select an ideal site where it would have a constant flow of wind throughout the year. For example, the Sindh province of Pakistan has several suitable sites for wind power generation.

\subsubsection{Political Factor (PF)}

This aspect involves the political commitment of the government to establish a wind project in a specific area. Political agreement from the government is essential for the approval and success of RE programs [78].

Government Policies (PF1)

The government must clearly state the renewable energy policies, guidelines, and installation plans. As well as the identified framework for the promotion and exploitation of the wind technology, which may encourage the wind project site selection. The institutional arrangement of RE technology is very significant for the deployment and achievement of a successful and long-term sustainable RE program [78].

\section{Land Acquisition (PF2)}

Two key organizations, the Pakistan Council of Renewable Energy Technologies (PCRET) and Alternative Energy Development Board (AEDB), are working for the development of renewable energy projects in the country [79]. Both organizations are responsible for facilitating the acquisition of the land for renewable energy projects because the maximum land is under the jurisdiction of the federal or provincial governments. Acquiring land is mainly dependent on the policies of the government for renewable projects; moreover, it is important that the land acquisition is framed in a timely manner in order to avoid delays.

Relocation and Rehabilitation (PF3)

From the political perspective, it is very important to consider the rights of the local people. If the land of farmers has been taken for the establishment of a power plant project in the area, an equal area of land must be provided to them at another area, or proper compensation may be paid to the people for relocation. Thus, the appropriate arrangement must be established in case of dislocation of the population is required [80]. 


\subsubsection{Social Factor (SF)}

Pakistan has failed to exploit the abundant renewable potential for sustainable development due to the negligence of the social aspect related to it. It is very important to involve local community people, otherwise, it may lead to common problems like land tenure, ownership issues, and refusal to pay for energy services. Thus, it is very critical to consider the social aspect of the society and deal with it in a suitable manner [81].

\section{Effect on Local Economic Development (SF1)}

Job creation is the socio-economic aspect which is associated with the installation and establishment of renewable energy and energy efficiency technologies [82]. Wind site selection adds to local economic development in that particular region. It provides jobs and develops infrastructural conditions of the region.

\section{Distance from Residential Areas (SF2)}

The establishment of RE power plants must not be within the circumstances of rural and urban residential areas otherwise it may impact on urban growth. Furthermore, it would be beneficial in the future to extend the capacity of the plant in the available land area [83]. It has been indicated that pessimistic attitudes of the local residents increase with the decrease in the distance of a power plant location from the residential area; as such, it is suggested that wind projects be constructed at the greatest distance away from residential areas [29,84].

Effect on Employment and Agriculture (SF3)

The selected wind power project must act as a source of employment for the local community and agriculture farming in the wind farm. The selected wind power project in the area must assist in increasing the employment opportunities for the people who have been suffering from unemployment for a long time [44].

\section{Social Acceptance (SF4)}

Public acceptance and perception is the main part of the development of RE projects [85]. The community of the local area may resist the wind project due to a lack of awareness about the socio-environmental benefits of wind energy in their region. The acceptance of the RE projects in the area depends on the psychological and personal factors of the local people, which are considered to be the key factors in the implementation of wind energy projects.

\subsection{AHP Results}

A group decision-making approach has been used in this study to determine the weights of the EETPS factors. Thus, a geometric mean has been employed for integrating individual experts' pairwise comparison matrices in calculating the weights of criteria and sub-criteria $[86,87]$. In the implementation of AHP methodology, in the first phase, the main criteria weights were obtained which were followed by the determination of sub-criteria weights as follows.

\subsubsection{Main Criteria Weights}

In this study, five main criteria were identified and subjected to pair-wise comparison to determine their weight as shown in Figure 3.

It is evident from the above results that the economic aspect is the most important criteria followed by the political, technical, environmental, and social aspects assessed by the AHP survey respondents. This assessment is very relevant as developing countries like Pakistan are often facing a daunting challenge to manage funds for the renewable energy projects development. 


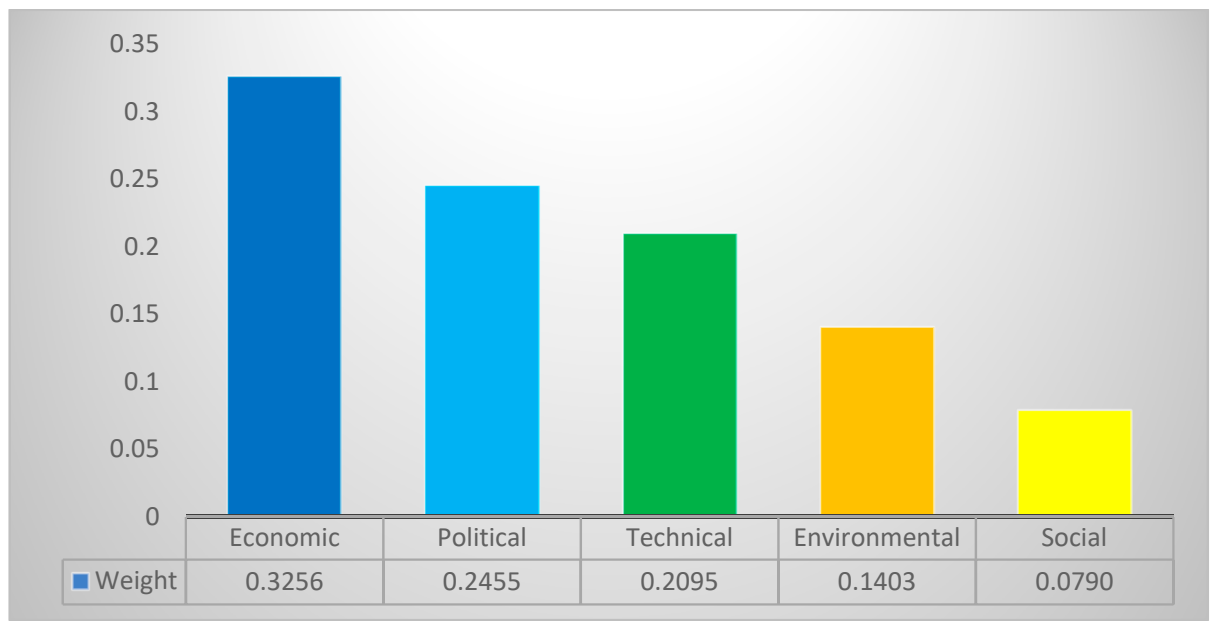

Figure 3. Ranking of criteria in wind project site selection in selected regions of Pakistan.

\subsubsection{Sub-Criteria Weights}

The sixteen sub-criteria of the study, devised using factor analysis, were assessed by the AHP survey respondents following the pair-wise comparison. The final weights of these sub-criteria and their relative rank are shown in Figures 4-9.

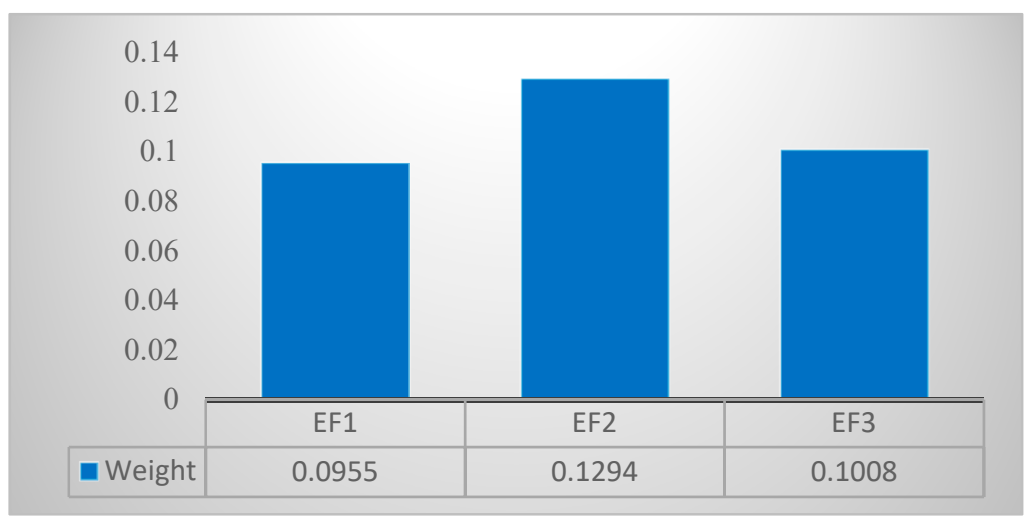

Figure 4. Economic sub-criteria weights.

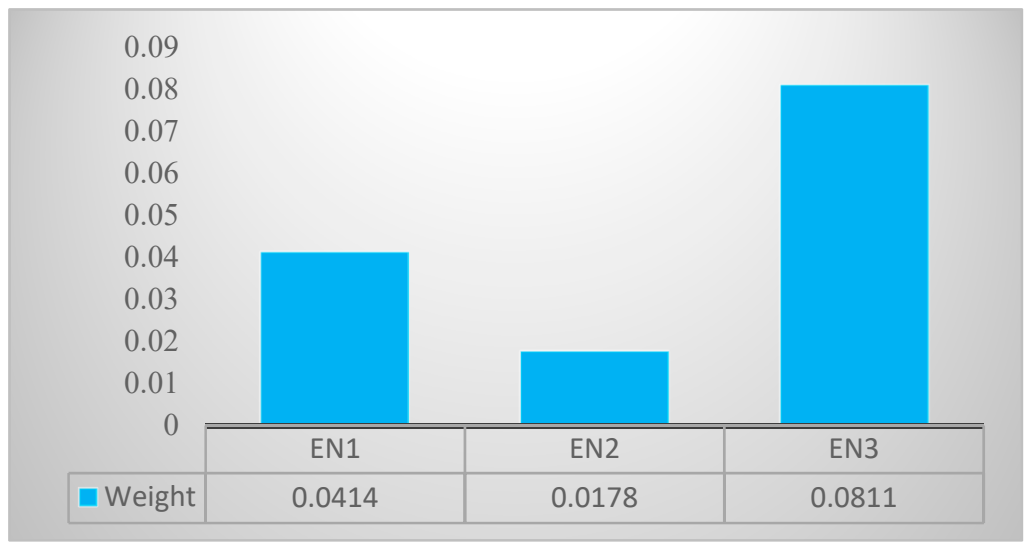

Figure 5. Environmental sub-criteria weights. 


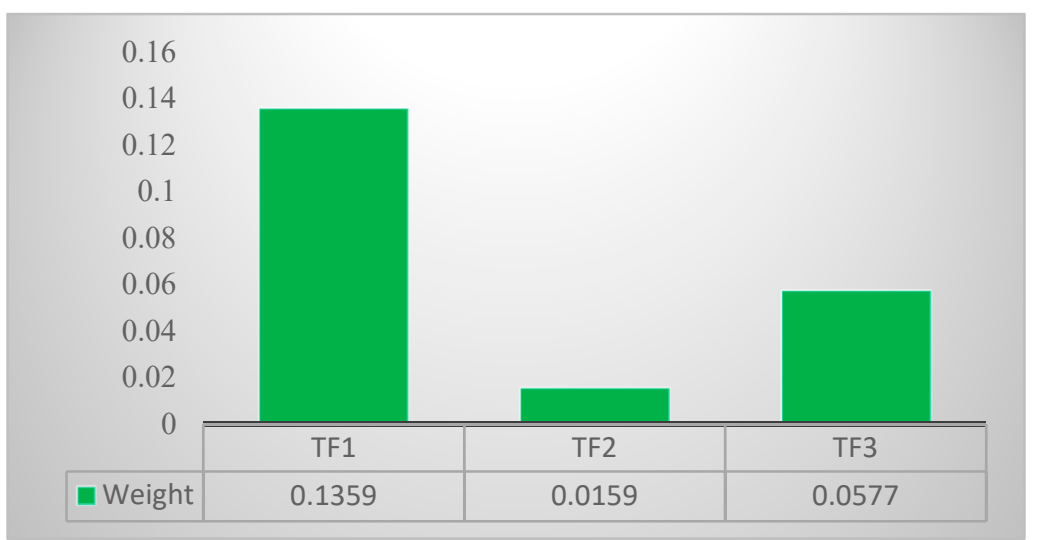

Figure 6. Technical sub-criteria weights.

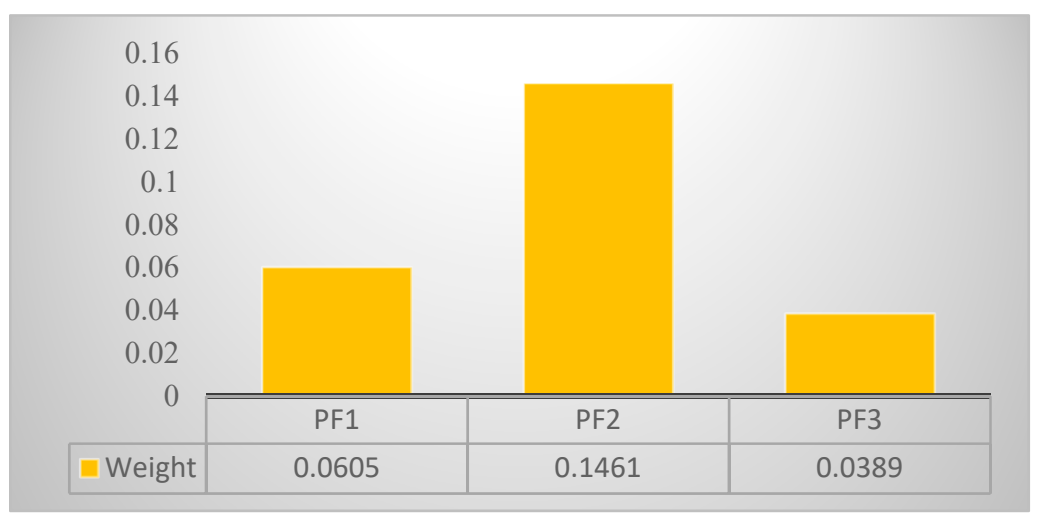

Figure 7. Political sub-criteria weights.

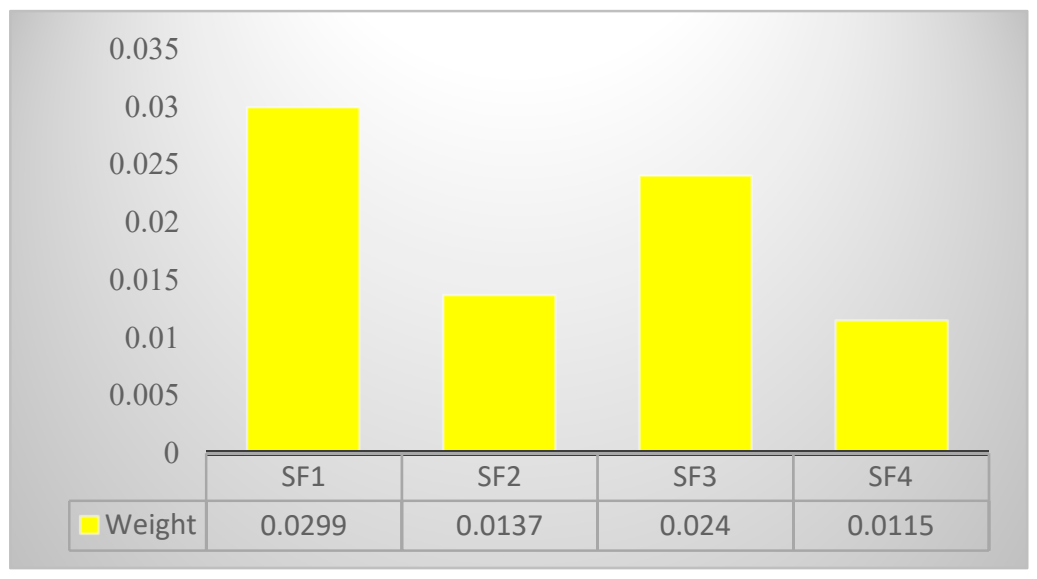

Figure 8. Social sub-criteria weights. 


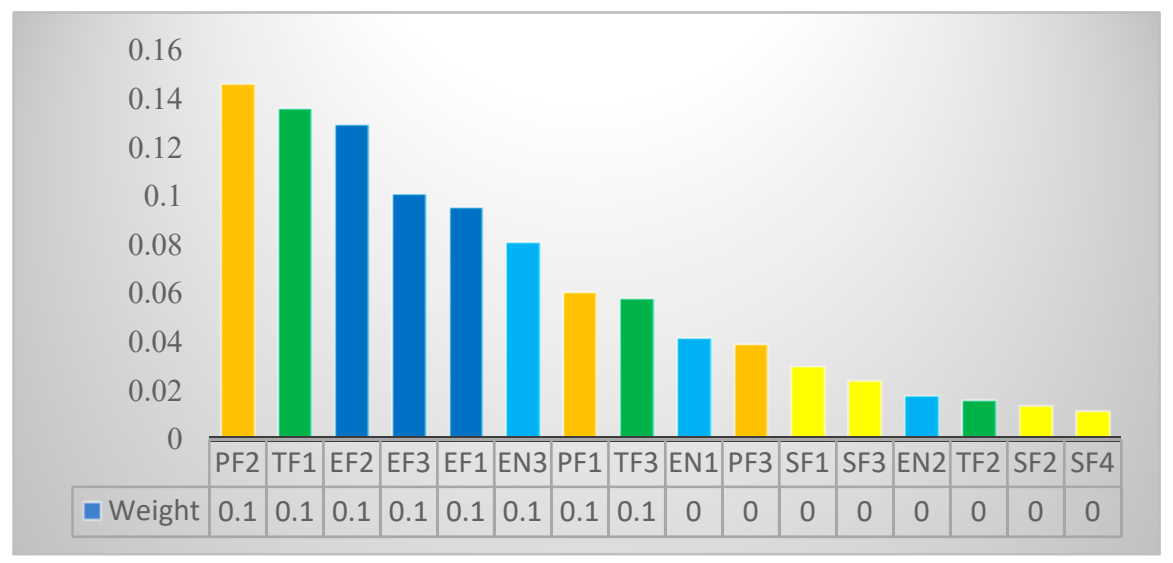

Figure 9. The overall ranking of sub-criteria in wind project site selection in selected regions of Pakistan.

\subsection{Fuzzy TOPSIS Results}

In this section, the ranking of wind sites (i.e., the decision alternatives of this study) have been analyzed using Fuzzy TOPSIS methodology. The analysis by the group of experts has established a fuzzy evaluation matrix into a triangular fuzzy number using linguistic variables. The linguistic variables rating matrix was obtained after the comparison of the alternatives against each sub-criterion.

This study has considered the EETPS factors under the cost criteria (i.e., EF1, EF2, EF3, EN1, EN2, TF2, TF3, PF1, PF2, PF3, SF2, SF4) and benefit criteria (i.e., EN3, TF1, SF1, SF3), respectively. Following, assigning the fuzzy positive ideal solution as $v^{+}=(1,1,1)$ and fuzzy negative ideal solution as $v^{-}=(0,0,0)$, respectively. The distance of each alternative was computed using Equations (13) and (14). The final ranking of the alternatives has been obtained in accordance with the coefficient closeness $C C_{i}$ values illustrated in Table 11.

The final ranking of the alternatives (wind sites) which has come of following rigorous factor analysis and implementation of AHP and Fuzzy TOPSIS methodologies is very relevant and provides insight into the reason for this ranking. The research framework of this study, therefore, provides very significant and refined results which can be of great help for energy planning and policy experts.

Table 11. The final ranking of the alternatives.

\begin{tabular}{cccccc}
\hline No. & Region & $\begin{array}{c}\text { Distance from Positive } \\
\text { Ideal Solution }\left(\boldsymbol{d}_{\boldsymbol{i}}^{+}\right)\end{array}$ & $\begin{array}{c}\text { Distance from Negative } \\
\text { Ideal Solution }\left(\boldsymbol{d}_{\boldsymbol{i}}^{-}\right)\end{array}$ & $\boldsymbol{C} \boldsymbol{C}_{\boldsymbol{i}}$ & Rank \\
\hline L3 & Jamshoro & 15.498 & 0.564 & 0.035 & 1 \\
L5 & Hyderabad & 15.554 & 0.494 & 0.031 & 2 \\
L2 & Nooriabad & 15.562 & 0.487 & 0.030 & 3 \\
L1 & Gharo & 15.573 & 0.469 & 0.029 & 4 \\
L4 & Ketibandar & 15.579 & 0.466 & 0.029 & 5 \\
L7 & Shahbandar & 15.595 & 0.442 & 0.028 & 6 \\
L8 & Sajawal & 15.615 & 0.420 & 0.026 & 7 \\
L6 & Talhar & 15.625 & 0.407 & 0.025 & 8 \\
\hline
\end{tabular}

\subsection{Sensitivity Analysis}

In the study, we have performed sensitivity analysis in order to know the feasibility and robustness of the obtained results by performing 19 tests. These tests are depicted in Table 12. All 19 tests were carried out to examine the effect of sub-criteria weights on the prioritization of alternatives. The sub-criteria weight for first 16 tests were assigned as the highest values, and others were allocated to low and identical weights. For instance, in test 1 the weight $\mathrm{W}_{\mathrm{EF} 1}$ of sub-criteria EF1 was assigned identical to 0.50, and for sub-criteria EF2-SF4 identical and lowest weights were 
allocated as $\mathrm{W}_{\mathrm{EF2}-\mathrm{SF} 4}=0.25$. The purpose of the test was to check the impact on prioritizing the order of alternatives. In test 17 , all sub-criteria weightage was assigned identical to 0.0505 . In test 18, the weight for sub-criteria EF1-SF4 was assigned as $\mathrm{W}_{\mathrm{EF1}-\mathrm{SF} 4}=0.0808$ and weight for PF3-SF4 sub-criteria was allocated identical to 0 (i.e., $\mathrm{W}_{\mathrm{PF} 3-\mathrm{SF} 4}=0$ ). Lastly, in test 19 , weight for sub-criteria EF1-PF2 was assigned as $\mathrm{W}_{\mathrm{EF} 1-\mathrm{PF} 2}=0$, and weight for PF3-SF4 sub-criteria was allocated identical to 0.20 (i.e., $\mathrm{W}_{\mathrm{PF} 3-\mathrm{SF} 3}=0.20$ ). The result of the sensitivity analysis is shown in Figure 10 . From Table 12 and Figure 10, it can be understood that the alternative L3 attained the favorable value in fourteen tests out of nineteen tests $(1-2,4-12$, and 16-18) while alternative L 5 shows the highest value in three tests $(3,13$, and 15$)$ and alternative $\mathrm{L} 2$ in two tests (14 and 19). Therefore, this study provides a robust and precise ranking of alternatives, and it is comparatively sensitive to the sub-criteria weights.

Table 12. Tests for sensitivity analysis.

\begin{tabular}{|c|c|c|c|c|c|c|c|c|c|c|}
\hline \multirow{2}{*}{ Test } & \multirow{2}{*}{ Definitions } & \multicolumn{8}{|c|}{ Coefficient Closeness $C C_{i}$} & \multirow{2}{*}{ Prioritizing Order } \\
\hline & & L1 & L2 & L3 & L4 & L5 & L6 & L7 & L8 & \\
\hline 1 & $\begin{array}{c}\mathrm{W}_{\mathrm{EF} 1}=0.50 \\
\mathrm{~W}_{\mathrm{EF2}-\mathrm{SF} 4}=0.025\end{array}$ & 0.030 & 0.032 & 0.036 & 0.029 & 0.032 & 0.026 & 0.028 & 0.027 & $\begin{array}{c}\mathrm{L} 3 \text { > L5 > L2 > L1 > } \\
\mathrm{L} 4>\mathrm{L} 7>\mathrm{L} 8>\mathrm{L} 6\end{array}$ \\
\hline 2 & $\begin{array}{c}\mathrm{W}_{\mathrm{EF} 2}=0.50 \\
\mathrm{~W}_{\mathrm{EF} 1, \mathrm{EF} 3-\mathrm{SF} 4}=0.025\end{array}$ & 0.029 & 0.031 & 0.036 & 0.029 & 0.033 & 0.025 & 0.028 & 0.026 & $\begin{array}{c}\mathrm{L} 3>\mathrm{L} 5>\mathrm{L} 2>\mathrm{L} 1> \\
\mathrm{L} 4>\mathrm{L} 7>\mathrm{L} 8>\mathrm{L} 6\end{array}$ \\
\hline 3 & $\begin{array}{c}\mathrm{W}_{\mathrm{EF} 3}=0.50 \\
\mathrm{~W}_{\mathrm{EF} 1-\mathrm{EF} 2, \mathrm{EN} 1-\mathrm{SF} 4}=0.025\end{array}$ & 0.033 & 0.032 & 0.034 & 0.031 & 0.035 & 0.029 & 0.028 & 0.027 & $\begin{array}{c}\mathrm{L} 5>\mathrm{L} 3>\mathrm{L} 1>\mathrm{L} 2> \\
\mathrm{L} 4>\mathrm{L} 6>\mathrm{L} 7>\mathrm{L} 8\end{array}$ \\
\hline 4 & $\begin{array}{c}\mathrm{W}_{\mathrm{EN} 1}=0.50 \\
\mathrm{~W}_{\mathrm{EF} 1-\mathrm{EF} 3, \mathrm{EN2}-\mathrm{SF} 4}=0.025\end{array}$ & 0.031 & 0.033 & 0.037 & 0.032 & 0.034 & 0.032 & 0.029 & 0.028 & $\begin{array}{c}\mathrm{L} 3 \text { > L5 > L2 > L6 > } \\
\mathrm{L} 4>\mathrm{L} 1>\mathrm{L} 7>\mathrm{L} 8\end{array}$ \\
\hline 5 & $\begin{array}{c}\mathrm{W}_{\mathrm{EN} 2}=0.50 \\
\mathrm{~W}_{\mathrm{EF1} 1 \mathrm{EN} 1, \mathrm{EN} 3-\mathrm{SF} 4}=0.025\end{array}$ & 0.033 & 0.030 & 0.035 & 0.031 & 0.033 & 0.026 & 0.032 & 0.032 & $\begin{array}{c}\mathrm{L} 3>\text { L1 }>\text { L5 }>\text { L7 }> \\
\text { L8 > L4 > L2 > L6 }\end{array}$ \\
\hline 6 & $\begin{array}{c}\mathrm{W}_{\mathrm{EN} 3}=0.50 \\
\mathrm{~W}_{\mathrm{EF1}-\mathrm{EN} 2, \mathrm{TF1}-\mathrm{SF} 4}=0.025\end{array}$ & 0.033 & 0.032 & 0.036 & 0.030 & 0.033 & 0.032 & 0.035 & 0.030 & $\begin{array}{c}\mathrm{L} 33>\mathrm{L} 7>\mathrm{L} 5>\mathrm{L} 1> \\
\mathrm{L} 6>\mathrm{L} 2>\mathrm{L} 8>\mathrm{L} 4\end{array}$ \\
\hline 7 & $\begin{array}{c}\mathrm{W}_{\mathrm{TF} 1}=0.50 \\
\mathrm{~W}_{\mathrm{EF1}-\mathrm{EN} 3, \mathrm{TF2}-\mathrm{SF} 4}=0.025\end{array}$ & 0.032 & 0.034 & 0.038 & 0.033 & 0.035 & 0.029 & 0.030 & 0.030 & $\begin{array}{c}\mathrm{L} 3 \text { > L5 > L2 > L4 > } \\
\mathrm{L} 1>\mathrm{L} 8>\mathrm{L} 7>\mathrm{L} 6\end{array}$ \\
\hline 8 & $\begin{array}{c}\mathrm{W}_{\mathrm{TF} 2}=0.50 \\
\mathrm{~W}_{\mathrm{EF1}-\mathrm{TF} 1, \mathrm{TF3}-\mathrm{SF} 4}=0.025\end{array}$ & 0.033 & 0.036 & 0.038 & 0.033 & 0.035 & 0.029 & 0.027 & 0.029 & $\begin{array}{c}\mathrm{L} 3>\text { L2 }>\text { L5 }>\text { L1 }> \\
\text { L4 }>\text { L8 > L6 > L7 }\end{array}$ \\
\hline 9 & $\begin{array}{c}\mathrm{W}_{\mathrm{TF} 3}=0.50 \\
\mathrm{~W}_{\mathrm{EF1}-\mathrm{TF2}, \mathrm{PF1}-\mathrm{SF} 4}=0.025\end{array}$ & 0.028 & 0.036 & 0.037 & 0.034 & 0.036 & 0.027 & 0.033 & 0.032 & $\begin{array}{c}\mathrm{L} 3 \text { > L } 5>\mathrm{L} 2>\mathrm{L} 4> \\
\mathrm{L} 7>\mathrm{L} 8>\mathrm{L} 1>\mathrm{L} 6\end{array}$ \\
\hline 10 & $\begin{array}{c}\mathrm{W}_{\mathrm{PF} 1}=0.50 \\
\mathrm{~W}_{\mathrm{EF1}-\mathrm{TF3}, \mathrm{PF2}-\mathrm{SF} 4}=0.025\end{array}$ & 0.028 & 0.032 & 0.035 & 0.031 & 0.031 & 0.032 & 0.033 & 0.029 & $\begin{array}{c}\mathrm{L} 3>\mathrm{L} 7>\mathrm{L} 6>\mathrm{L} 5> \\
\mathrm{L} 2>\mathrm{L} 4>\mathrm{L} 8>\mathrm{L} 1\end{array}$ \\
\hline 11 & $\begin{array}{c}\mathrm{W}_{\mathrm{PF} 2}=0.50 \\
\mathrm{~W}_{\mathrm{EF1}-\mathrm{PF1}, \mathrm{PF3}-\mathrm{SF} 4}=0.025\end{array}$ & 0.036 & 0.032 & 0.039 & 0.034 & 0.036 & 0.033 & 0.031 & 0.031 & $\begin{array}{c}\mathrm{L} 3>\mathrm{L} 1>\mathrm{L} 5>\mathrm{L} 4> \\
\mathrm{L} 6>\mathrm{L} 2>\mathrm{L} 7>\mathrm{L} 8\end{array}$ \\
\hline 12 & $\begin{array}{c}\mathrm{W}_{\mathrm{PF} 3}=0.50 \\
\mathrm{~W}_{\mathrm{EF1}-\mathrm{PF2}, \mathrm{SF1}-\mathrm{SF} 4}=0.025\end{array}$ & 0.035 & 0.037 & 0.041 & 0.035 & 0.036 & 0.034 & 0.033 & 0.032 & $\begin{array}{c}\mathrm{L} 33>\mathrm{L} 2>\mathrm{L} 5>\mathrm{L} 4> \\
\mathrm{L} 1>\mathrm{L} 6>\mathrm{L} 7>\mathrm{L} 8\end{array}$ \\
\hline 13 & $\begin{array}{c}\mathrm{W}_{\mathrm{SF} 1}=0.50 \\
\mathrm{~W}_{\mathrm{EF1}-\mathrm{PF} 3, \mathrm{SF2}-\mathrm{SF} 4}=0.025\end{array}$ & 0.035 & 0.037 & 0.036 & 0.034 & 0.038 & 0.026 & 0.033 & 0.031 & $\begin{array}{c}\mathrm{L} 5>\mathrm{L} 2>\mathrm{L} 3>\mathrm{L} 1> \\
\mathrm{L} 4>\mathrm{L} 7>\mathrm{L} 8>\mathrm{L} 6\end{array}$ \\
\hline 14 & $\begin{array}{c}\mathrm{W}_{\mathrm{SF} 2}=0.50 \\
\mathrm{~W}_{\mathrm{EF1}-\mathrm{SF} 1, \mathrm{SF3}-\mathrm{SF} 4}=0.025\end{array}$ & 0.034 & 0.037 & 0.035 & 0.034 & 0.036 & 0.030 & 0.030 & 0.033 & $\begin{array}{c}\mathrm{L} 2>\mathrm{L} 5>\mathrm{L} 3>\mathrm{L} 1> \\
\mathrm{L} 4>\mathrm{L} 8>\mathrm{L} 6>\mathrm{L} 7\end{array}$ \\
\hline 15 & $\begin{array}{c}\mathrm{W}_{\mathrm{SF} 3}=0.50 \\
\mathrm{~W}_{\mathrm{EF} 1-\mathrm{SF} 2, \mathrm{SF} 4}=0.025\end{array}$ & 0.036 & 0.035 & 0.034 & 0.036 & 0.040 & 0.032 & 0.030 & 0.030 & $\begin{array}{c}\mathrm{L} 5>\mathrm{L} 1>\mathrm{L} 4>\mathrm{L} 2> \\
\mathrm{L} 3>\mathrm{L} 6>\mathrm{L} 7>\mathrm{L} 8\end{array}$ \\
\hline 16 & $\begin{array}{c}\mathrm{W}_{\mathrm{SF} 4}=0.50 \\
\mathrm{~W}_{\mathrm{EF} 1-\mathrm{SF} 3}=0.025\end{array}$ & 0.038 & 0.039 & 0.040 & 0.035 & 0.036 & 0.027 & 0.029 & 0.028 & $\begin{array}{c}\mathrm{L} 3>\mathrm{L} 2>\mathrm{L} 1>\mathrm{L} 5> \\
\mathrm{L} 4>\mathrm{L} 7>\mathrm{L} 8>\mathrm{L} 6\end{array}$ \\
\hline 17 & $\mathrm{~W}_{\mathrm{EF1-SF4}}=0.0505$ & 0.037 & 0.039 & 0.043 & 0.036 & 0.040 & 0.029 & 0.034 & 0.033 & $\begin{array}{c}\mathrm{L} 3>\mathrm{L} 5>\mathrm{L} 2>\mathrm{L} 1> \\
\mathrm{L} 4>\mathrm{L} 7>\mathrm{L} 8>\mathrm{L} 6\end{array}$ \\
\hline 18 & $\begin{array}{c}\mathrm{W}_{\mathrm{EF1-PF2}}=0.0808, \\
\mathrm{~W}_{\mathrm{PF}-\mathrm{SF} 4}=0\end{array}$ & 0.036 & 0.034 & 0.039 & 0.035 & 0.036 & 0.031 & 0.032 & 0.033 & $\begin{array}{c}\mathrm{L} 3>\mathrm{L} 1>\mathrm{L} 5>\mathrm{L} 4> \\
\mathrm{L} 2>\mathrm{L} 8>\mathrm{L} 7>\mathrm{L} 6\end{array}$ \\
\hline 19 & $\begin{array}{c}\mathrm{W}_{\mathrm{EF} 1-\mathrm{PF} 2}=0, \\
\mathrm{~W}_{\mathrm{PF} 3-\mathrm{SF} 4}=0.20\end{array}$ & 0.029 & 0.034 & 0.031 & 0.028 & 0.030 & 0.029 & 0.032 & 0.032 & $\begin{array}{c}\mathrm{L} 2>\mathrm{L} 8>\mathrm{L} 7>\mathrm{L} 3> \\
\mathrm{L} 5>\mathrm{L} 6>\mathrm{L} 1>\mathrm{L} 4\end{array}$ \\
\hline
\end{tabular}




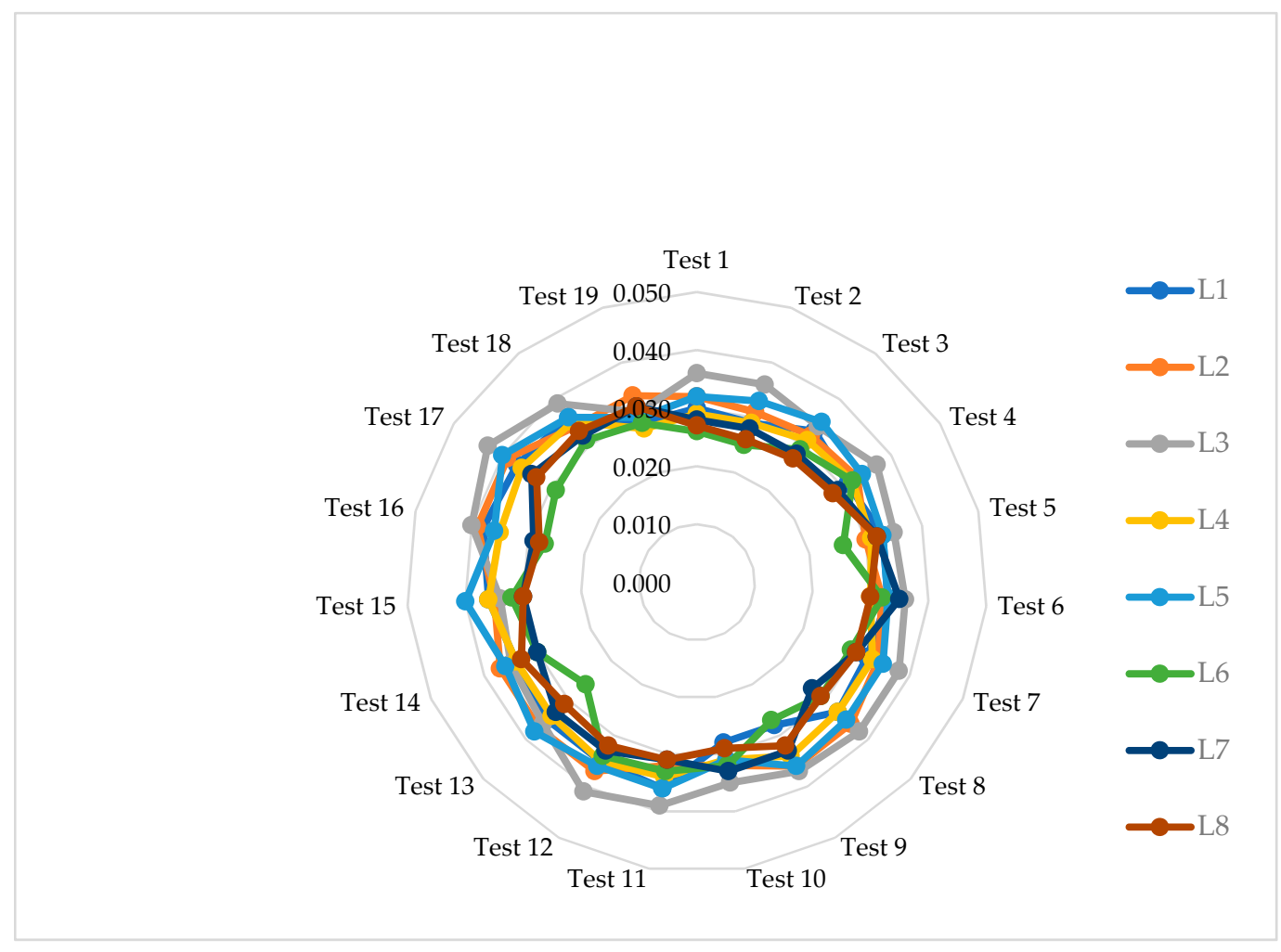

Figure 10. The result of the sensitivity analysis.

\section{Discussion and Recommendations}

This study's comprehensive research framework and implementation provided important insights pertaining the different methodologies which are very relevant and the results which are very significant. As such, this study lays a foundation for energy planners and policy-makers to consider the research framework as well as the pertinent results of this study which also provide an appropriate rationalization for wind project site selection. The factor analysis and MCDM methods have been used effectively to address the of wind power project site selection decision making out of eight locations in the southeastern region of Pakistan. The results of the study are not only supported by a rich methodology, expert opinion and related work was also utilized appropriately. Amongst the five main criteria of the study (i.e., economic, technical, environmental, political, and social factors), the economic factor has been identified as the most significant factor, and the social aspect is considered by the respondents as of the lowest priority. This ranking of the main criteria is evident from a typical developing country perspective wherein a funding resource paucity is a key challenge faced to develop renewable energy projects. However, although the lowest ranking of the social factor is not encouraging, it reflects the lower awareness of the masses pertaining to their rights and privileges to impact the national level decision-making. The sub-criteria priority result ranks the land acquisition, wind data availability and on-grid accessibility as the first, second, and third-ranked factors. The summary ranking of the sixteen sub-criteria is such that the top-ranked criteria follow as $\mathrm{PF} 2>\mathrm{TF} 1>\mathrm{EF} 2>\mathrm{EF} 3>\mathrm{EF} 1>\mathrm{EN} 3>\mathrm{PF} 1>\mathrm{TF} 2$, and the lowest rankers were $\mathrm{SF} 4<\mathrm{SF} 2<\mathrm{TF} 3<$ $\mathrm{EN} 1<\mathrm{PF} 3<\mathrm{SF} 1<\mathrm{SF} 3<\mathrm{EN} 2$. The sub-criteria ranking of land acquisition, wind data availability, and on-grid accessibility is all reflective of a very robust outcome. All these three criteria are vital and very important to any decision pertaining to the site selection for wind power projects.

In the implementation of AHP and Fuzzy TOPSIS methodology, the wind power project location having the highest $C C_{i}$ value was ranked as the most appropriate site for the development of the wind power project. As such, results recommend Jamshoro as the best suited location followed by Hyderabad, Nooriabad, Gharo, Ketibandar, Shahbandar, Sajawal, and Talhar, respectively. 
This prioritized ranking of different locations of the southeastern wind corridor of the province is very important since it was accomplished using a scientific decision project and took into account essential factors as well as a robust methodology. Jamshoro, Hyderabad, and Nooribad are, therefore, recommended as the most suitable locations for investment and development of wind power projects. All these locations have sufficient windy days across the year and with appropriate roads and other infrastructure around. As discussed in the earlier section of the paper, the GoP have already taken the initiative to harness renewable energy potential, with wind energy as the most promising source, which could be a great relief for the country in addressing the ongoing energy crises. In this context, this study can help decision-makers and government authorities in the prioritization of feasible locations and installation of wind power plants at southeastern regions, as well as other windy regions of the country.

\section{Conclusions}

Wind energy has an enormous potential for sustainable development by providing various benefits such as diversifying the energy mix from fossil fuels to renewable energy, increasing national and regional economic growth, as well as increasing employment opportunities. Thus, it is very important to prioritize feasible locations for the development of wind power projects, which is a multifaceted decision process. Taking into consideration the fact that there is no comprehensive decision support framework for wind project site selection in Pakistan, this study attempted to address this research gap and proposed a research framework for wind project site selection in the Southeastern region of Pakistan. This study identified main-criteria and further using expert feedback determined the sub-criteria through factor analysis. In the process of the implementation of AHP and Fuzzy TOPSIS decision models, experts from academia, industry, stakeholders, and government were part of the study to provide their perceptive judgment pertaining to decision alternatives. Economic and land acquisition criteria have emerged as top-ranked main and sub-criteria of the study. The results of this study decision support framework reveal Jamshoro as the most optimal location for the wind energy development followed by Hyderabad, Nooriabad, Gharo, Keti Bandar, Shahbandar, Sajawal, and Talhar. The Fuzzy TOPSIS methodology was found helpful in refining the AHP results, minimizing any uncertainty, and addressing any imprecision in the group decision-making.

In summary, this research study has developed a comprehensive decision support framework to assess the optimal site selection for wind project development in the southeastern wind corridor of Pakistan. The results of the study are robust and meet technical and other relevant criteria often ignored in wind power project site selection. As the outcome of this study is based on the judgment of the experts' feedback at each level of the assessment process, therefore, different experts and more inclusion of stakeholders as well application of other methods of the MCDM may slightly impact the results. In the meantime, this study is very important and relevant to be considered at an appropriate level for the wind power project site selection as well as for further enhancements.

Author Contributions: All the authors contributed to this work. Y.A.S. and Q.T. conceived and structured the study. Y.A.S. undertook the survey and along with Q.T. developed the methodology and preliminary manuscript. N.H.M., M.W.A.K. and I.A. analyzed the model results and finalized the manuscript.

Funding: This study is supported by the Social Science Foundation of China (15BGL029) and the Social Science Fund Major Project of Jiangsu Province (16ZD008).

Conflicts of Interest: The authors declare no conflict of interest.

\section{Acronyms}

FA

SPSS

MCDM

AHP

FTOPSIS

RE
Factor Analysis

Statistical Package for the Social Sciences

Multi-Criteria Decision Making

Analytical Hierarchy Process

Fuzzy Technique for Order of Preference by Similarity to Ideal Solution

Renewable Energy 


$\begin{array}{ll}\text { GoP } & \text { Government of Pakistan } \\ \text { EETPS } & \text { Economic, Environmental, Technical, Political, and Social } \\ \text { CI } & \text { Consistency Index } \\ \text { CR } & \text { Consistency Ratio } \\ \text { RI } & \text { Random Index } \\ \text { TFNs } & \text { Triangular Fuzzy Numbers }\end{array}$

\section{References}

1. Ashraf, C.M.; Raza, R.; Hayat, S.A. Renewable Energy Technologies in Pakistan: Prospects and Challenges. Renew. Sustain. Energy Rev. 2009, 13, 1657-1662. [CrossRef]

2. Zabel, G. Peak People: The Interrelationship between Population Growth and Energy Resources. Energy Bull. 2009. Available online: http:/ / www2.energybulletin.net/node/48677 (accessed on 24 July 2018).

3. Thapar, S.; Sharma, S.; Verma, A. Economic and Environmental Effectiveness of Renewable Energy Policy Instruments: Best Practices from India. Renew. Sustain. Energy Rev. 2016, 66, 487-498. [CrossRef]

4. Pryor, S.C.; Barthelmie, R.J. Climate Change Impacts on Wind Energy: A Review. Renew. Sustain. Energy Rev. 2010, 14, 430-437. [CrossRef]

5. Zameer, H.; Wang, Y. Energy Production System Optimization: Evidence from Pakistan. Renew. Sustain. Energy Rev. 2018, 82, 886-893. [CrossRef]

6. Ghafoor, A.; Rehman, T.U.; Munir, A.; Ahmad, M.; Iqbal, M. Current Status and Overview of Renewable Energy Potential in Pakistan for Continuous Energy Sustainability. Renew. Sustain. Energy Rev. 2016, 60, 1332-1342. [CrossRef]

7. Shami, S.H.; Ahmad, J.; Zafar, R.; Haris, M.; Bashir, S. Evaluating Wind Energy Potential in Pakistan's Three Provinces, with Proposal for Integration into National Power Grid. Renew. Sustain. Energy Rev. 2016, 53, 408-421. [CrossRef]

8. Ministry of Energy. Alternative Energy Development Board. Available online: http://aedb.org/aetechnologies / wind-power/wind-current-status (accessed on 14 March 2018).

9. Sánchez-Lozano, J.M.; García-Cascales, M.S.; Lamata, M.T. Identification and Selection of Potential Sites for Onshore Wind Farms Development in Region of Murcia, Spain. Energy 2014, 73, 311-324. [CrossRef]

10. Weißbach, D.; Ruprecht, G.; Huke, A.; Czerski, K.; Gottlieb, S.; Hussein, A. Energy Intensities, EROIs (Energy Returned on Invested), and Energy Payback Times of Electricity Generating Power Plants. Energy 2013, 52 , 210-221. [CrossRef]

11. Georgiadis, D.R.; Mazzuchi, T.A.; Sarkani, S. Using Multi Criteria Decision Making in Analysis of Alternatives for Selection of Enabling Technology. Syst. Eng. 2013, 16, 287-303. [CrossRef]

12. Saaty, T.L. The Analytic Hierarchy Process. Eur. J. Oper. Res. 1990, 48, 9-26. [CrossRef]

13. Chang, H.-K.; Liou, J.-C.; Chen, W.-W. Protection Priority in the Coastal Environment Using a Hybrid AHP-TOPSIS Method on the Miaoli Coast, Taiwan. J. Coast. Res. 2012, 280, 369-374. [CrossRef]

14. Pakistan Bureau of Statistics 6th Population and Housing Census. Government of Pakistan. Available online: http://www.pbs.gov.pk/content/provisional-summary-results-6th-population-andhousing-census-2017-0 (accessed on 24 July 2018).

15. Sindh Energy Department. Alternative Energy Potential in Sindh. Available online: http:/ /sindhenergy.gov. pk/investment-opportunity/investment-opportunity-in-alternate-energy/ (accessed on 25 April 2018).

16. Khan, I.; Chowdhury, H.; Rasjidin, R.; Alam, F.; Islam, T.; Islam, S. Review of Wind Energy Utilization in South Asia. Procedia Eng. 2012, 49, 213-220. [CrossRef]

17. Pakistan Meteorological Department. WIND ENERGY PROJECT. Available online: http://www.pmd.gov. pk/wind/Wind_Project_files/Page406.html (accessed on 25 April 2018).

18. Badger, J.; Badger, M.; Kelly, M.; Guo Larsén, X. Global Wind Atlas. Available online: https:// globalwindatlas.info/ (accessed on 9 July 2018).

19. Bhutto, A.W.; Bazmi, A.A.; Zahedi, G. Greener Energy: Issues and Challenges for Pakistan-Wind Power Prospective. Renew. Sustain. Energy Rev. 2013, 20, 519-538. [CrossRef]

20. Baloch, M.H.; Abro, S.A.; Kaloi, G.S.; Mirjat, N.H.; Tahir, S.; Nadeem, M.H.; Gul, M.; Memon, Z.A.; Kumar, M. A Research on Electricity Generation from Wind Corridors of Pakistan (Two Provinces): A Technical Proposal for Remote Zones. Sustainability 2017, 9, 1611. [CrossRef] 
21. Baloch, M.H.; Kaloi, G.S.; Memon, Z.A. Current Scenario of the Wind Energy in Pakistan Challenges and Future Perspectives: A Case Study. Energy Rep. 2016, 2, 201-210. [CrossRef]

22. Thorndike, R.M. History of Factor Analysis: A Psychological Perspective; Wiley Online Library, Western Washington University: Bellingham, WA, USA, 2005.

23. Waris, M.; Shahir Liew, M.; Khamidi, M.F.; Idrus, A. Criteria for the Selection of Sustainable Onsite Construction Equipment. Int. J. Sustain. Built Environ. 2014, 3, 96-110. [CrossRef]

24. Braeken, J.; Van Assen, M.A.L.M. An Empirical Kaiser Criterion. Psychol. Methods 2017, 22, 450-466.

25. Maynard, J.E.; Lovecraft, A.; Rose, C.; Chapin, T., III. Factors Influencing the Development of Wind Power in Rural Alaska Communities. Available online: https://www.uaf.edu/files/rap/Maynard-thesis.pdf (accessed on 24 July 2018).

26. Latinopoulos, D.; Kechagia, K. A GIS-Based Multi-Criteria Evaluation for Wind Farm Site Selection. A Regional Scale Application in Greece. Renew. Energy 2015, 78, 550-560. [CrossRef]

27. Azizi, A.; Malekmohammadi, B.; Jafari, H.R.; Nasiri, H.; Amini Parsa, V. Land Suitability Assessment for Wind Power Plant Site Selection Using ANP-DEMATEL in a GIS Environment: Case Study of Ardabil Province, Iran. Environ. Monit. Assess. 2014, 186, 6695-6709. [CrossRef] [PubMed]

28. Al-Yahyai, S.; Charabi, Y.; Gastli, A.; Al-Badi, A. Wind Farm Land Suitability Indexing Using Multi-Criteria Analysis. Renew. Energy 2012, 44, 80-87. [CrossRef]

29. Tegou, L.-I.; Polatidis, H.; Haralambopoulos, D.A. Environmental Management Framework for Wind Farm Siting: Methodology and Case Study. J. Environ. Manag. 2010, 91, 2134-2147. [CrossRef] [PubMed]

30. Gigović, L.; Pamučar, D.; Božanić, D.; Ljubojević, S. Application of the GIS-DANP-MABAC Multi-Criteria Model for Selecting the Location of Wind Farms: A Case Study of Vojvodina, Serbia. Renew. Energy 2017, 103, 501-521. [CrossRef]

31. Noorollahi, Y.; Yousefi, H.; Mohammadi, M. Multi-Criteria Decision Support System for Wind Farm Site Selection Using GIS. Sustain. Energy Technol. Assess. 2016, 13, 38-50. [CrossRef]

32. Ali, Y.; Butt, M.; Sabir, M.; Mumtaz, U.; Salman, A. Selection of Suitable Site in Pakistan for Wind Power Plant Installation Using Analytic Hierarchy Process (AHP). J. Control Decis. 2017, 5, 117-128. [CrossRef]

33. Pamučar, D.; Gigović, L.; Bajić, Z.; Janošević, M. Location Selection for Wind Farms Using GIS Multi-Criteria Hybrid Model: An Approach Based on Fuzzy and Rough Numbers. Sustainability 2017, 9, 1315. [CrossRef]

34. Yeh, T.M.; Huang, Y.L. Factors in Determining Wind Farm Location: Integrating GQM, Fuzzy DEMATEL, and ANP. Renew. Energy 2014, 66, 159-169. [CrossRef]

35. Wątróbski, J.; Ziemba, P.; Jankowski, J.; Zioło, M. Green Energy for a Green City-A Multi-Perspective Model Approach. Sustainability 2016, 8, 702. [CrossRef]

36. Wątróbski, J.; Ziemba, P.; Wolski, W. Methodological Aspects of Decision Support System for the Location of Renewable Energy Sources. In Proceedings of the Computer Science and Information Systems (FedCSIS), 2015 Federated Conference, Lodz, Poland, 13 September 2015; pp. 1451-1459.

37. Wu, Y.; Zhang, J.; Yuan, J.; Geng, S.; Zhang, H. Study of Decision Framework of Offshore Wind Power Station Site Selection Based on ELECTRE-III under Intuitionistic Fuzzy Environment: A Case of China. Energy Convers. Manag. 2016, 113, 66-81. [CrossRef]

38. Sánchez-Lozano, J.M.; García-Cascales, M.S.; Lamata, M.T. GIS-Based Onshore Wind Farm Site Selection Using Fuzzy Multi-Criteria Decision Making Methods. Evaluating the Case of Southeastern Spain. Appl. Energy 2016, 171, 86-102. [CrossRef]

39. Azadeh, A.; Ghaderi, S.F.; Nasrollahi, M.R. Location Optimization of Wind Plants in Iran by an Integrated Hierarchical Data Envelopment Analysis. Renew. Energy 2011, 36, 1621-1631. [CrossRef]

40. Azadeh, A.; Rahimi-Golkhandan, A.; Moghaddam, M. Location Optimization of Wind Power Generation-Transmission Systems under Uncertainty Using Hierarchical Fuzzy DEA: A Case Study. Renew. Sustain. Energy Rev. 2014, 30, 877-885. [CrossRef]

41. Michaud, D.S.; Feder, K.; Keith, S.E.; Voicescu, S.A.; Marro, L.; Than, J.; Guay, M.; Denning, A.; McGuire, D.; Bower, T.; et al. Exposure to Wind Turbine Noise: Perceptual Responses and Reported Health Effects. J. Acoust. Soc. Am. 2016, 139, 1443-1454. [CrossRef] [PubMed]

42. Baseer, M.A.; Rehman, S.; Meyer, J.P.; Alam, M.M. GIS-Based Site Suitability Analysis for Wind Farm Development in Saudi Arabia. Energy 2017, 141, 1166-1176. [CrossRef]

43. Sonnberger, M.; Ruddat, M. Local and Socio-Political Acceptance of Wind Farms in Germany. Technol. Soc. 2017, 51, 56-65. [CrossRef] 
44. Del Río, P.; Burguillo, M. An Empirical Analysis of the Impact of Renewable Energy Deployment on Local Sustainability. Renew. Sustain. Energy Rev. 2009, 13, 1314-1325. [CrossRef]

45. Ervural, B.C.; Evren, R.; Delen, D. A Multi-Objective Decision-Making Approach for Sustainable Energy Investment Planning. Renew. Energy 2018, 126, 387-402. [CrossRef]

46. Browne, D.; O'Regan, B.; Moles, R. Use of Multi-Criteria Decision Analysis to Explore Alternative Domestic Energy and Electricity Policy Scenarios in an Irish City-Region. Energy 2010, 35, 518-528. [CrossRef]

47. Mirjat, N.H.; Uqaili, M.A.; Harijan, K.; Mustafa, M.W.; Rahman, M.M.; Khan, M.W.A. Multi-Criteria Analysis of Electricity Generation Scenarios for Sustainable Energy Planning in Pakistan. Energies 2018, 11, 757. [CrossRef]

48. Hwang, C.-L.; Yoon, K. Methods for Multiple Attribute Decision Making. In Multiple Attribute Decision Making: Methods and Applications A State-of-the-Art Survey. Mult. Attrib. Decis. Mak. 1981, 1, 58-191.

49. Saaty, T.L. The Analytic Hierarchy Process: Planning, Priority Setting. Resour. Alloc. 1980, 2, 287.

50. Charnes, A.; Cooper, W.W.; Rhodes, E. Measuring the Efficiency of Decision Making Units. Eur. J. Oper. Res. 1978, 2, 429-444. [CrossRef]

51. Dyer, J.S. Maut-Multiattribute Utility Theory. In Multiple Criteria Decision Analysis: State of the Art Surveys; Springer: New York, NY, USA, 2005; Volume 78, pp. 265-295.

52. Atilgan, B.; Azapagic, A. An Integrated Life Cycle Sustainability Assessment of Electricity Generation in Turkey. Energy Policy 2016, 93, 168-186. [CrossRef]

53. Brans, J.P.; Vincke, P.; Mareschal, B. How to Select and How to Rank Projects: The Promethee Method. Eur. J. Oper. Res. 1986, 24, 228-238. [CrossRef]

54. Bana E Costa, C.A.; De Corte, J.M.; Vansnick, J.C. On the Mathematical Foundations of MACBETH. Int. Ser. Oper. Res. Manag. Sci. 2016, 233, 421-463.

55. Kumar, A.; Sah, B.; Singh, A.R.; Deng, Y.; He, X.; Kumar, P.; Bansal, R.C. A Review of Multi Criteria Decision Making (MCDM) towards Sustainable Renewable Energy Development. Renew. Sustain. Energy Rev. 2017, 69, 596-609. [CrossRef]

56. Ziemba, P.; Watróbski, J.; Zioło, M.; Karczmarczyk, A. Using the PROSA Method in Offshore Wind Farm Location Problems. Energies 2017, 10, 1755. [CrossRef]

57. Ziemba, P. NEAT F-PROMETHEE-A New Fuzzy Multiple Criteria Decision Making Method Based on the Adjustment of Mapping Trapezoidal Fuzzy Numbers. Expert Syst. Appl. 2018, 110, 363-380. [CrossRef]

58. Wang, J.J.; Jing, Y.Y.; Zhang, C.F.; Zhao, J.H. Review on Multi-Criteria Decision Analysis Aid in Sustainable Energy Decision-Making. Renew. Sustain. Energy Rev. 2009, 13, 2263-2278. [CrossRef]

59. Alexander, M. Decision-Making Using the Analytic Hierarchy Process (AHP) and JMP ${ }^{\circledR}$ Scripting Language. Available online: http://www.jmp.com/about/events/summit2012/resources/Paper_Melvin_Alexander. pdf (accessed on 24 July 2018).

60. Saaty, T.L. Decision Making with the Analytic Hierarchy Process. Int. J. Serv. Sci. 2008, 1, 83. [CrossRef]

61. Song, B.; Kang, S. A Method of Assigning Weights Using a Ranking and Nonhierarchy Comparison. Adv. Decis. Sci. 2016, 2016, 9. [CrossRef]

62. Afsordegan, A.; Sánchez, M.; Agell, N.; Zahedi, S.; Cremades, L.V. Decision Making under Uncertainty Using a Qualitative TOPSIS Method for Selecting Sustainable Energy Alternatives. Int. J. Environ. Sci. Technol. 2016, 13, 1419-1432. [CrossRef]

63. Zare, K.; Mehri-Tekmeh, J.; Karimi, S. A SWOT Framework for Analyzing the Electricity Supply Chain Using an Integrated AHP Methodology Combined with Fuzzy-TOPSIS. Int. Strateg. Manag. Rev. 2015, 3, 66-80. [CrossRef]

64. Han, H.; Trimi, S. A Fuzzy TOPSIS Method for Performance Evaluation of Reverse Logistics in Social Commerce Platforms. Expert Syst. Appl. 2018, 103, 133-145. [CrossRef]

65. Roszkowska, E.; Wachowicz, T. Application of Fuzzy TOPSIS to Scoring the Negotiation Offers in Ill-Structured Negotiation Problems. Eur. J. Oper. Res. 2015, 242, 920-932. [CrossRef]

66. Vafaeipour, M.; Hashemkhani, Z.S.; Morshed, V.M.H.; Derakhti, A.; Keshavarz, E.M. Assessment of Regions Priority for Implementation of Solar Projects in Iran: New Application of a Hybrid Multi-Criteria Decision Making Approach. Energy Convers. Manag. 2014, 86, 653-663. [CrossRef]

67. Janke, J.R. Multicriteria GIS Modeling of Wind and Solar Farms in Colorado. Renew. Energy 2010, 35, 2228-2234. [CrossRef] 
68. Joseph Owen Roberts and Gail Mosey. Technical and Economic Feasibility Study of Utility-Scale Wind at the Doepke-Holliday Superfund Site. Available online: https:/ / www.nrel.gov/docs/fy13osti/57674.pdf (accessed on 3 January2018).

69. Luthra, S.; Kumar, S.; Kharb, R.; Ansari, M.F.; Shimmi, S.L. Adoption of Smart Grid Technologies: An Analysis of Interactions among Barriers. Renew. Sustain. Energy Rev. 2014, 33, 554-565. [CrossRef]

70. Baban, S.M.J.; Parry, T. Developing and Applying a GIS-Assisted Approach to Locating Wind Farms in the UK. Renew. Energy 2001, 24, 59-71. [CrossRef]

71. McCunney, R.J.; Mundt, K.A.; Colby, W.D.; Dobie, R.; Kaliski, K.; Blais, M. Wind Turbines and Health. J. Occup. Environ. Med. 2015, 56, e133-e135. [CrossRef] [PubMed]

72. UCSUSA. Environmental Impacts of Wind Power. Available online: http:/ /www.ucsusa.org/clean-energy / renewable-energy/environmental-impacts-wind-power (accessed on 26 December 2017).

73. National Renewable Energy Laboratory (NREL). Renewable Electricity Futures Study. U.S. Dep. Energy 2012, $1,280$.

74. Tocco, H. A Few Guidelines for Selecting Sites. Available online: http:/ /www.windpowerengineering.com/ projects / guidelines-selecting-sites / (accessed on 3 January 2018).

75. Rehman, S.; Halawani, T.; Mohandes, M. Wind Power Cost Assessment at Twenty Locations in the Kingdom of Saudi Arabia. Renew. Energy 2003, 28, 573-583. [CrossRef]

76. Villacreses, G.; Gaona, G.; Martínez-Gómez, J.; Jijón, D.J. Wind Farms Suitability Location Using Geographical Information System (GIS), Based on Multi-Criteria Decision Making (MCDM) Methods: The Case of Continental Ecuador. Renew. Energy 2017, 109, 275-286. [CrossRef]

77. Rezaei-Shouroki, M.; Mostafaeipour, A.; Qolipour, M. Prioritizing of Wind Farm Locations for Hydrogen Production: A Case Study. Int. J. Hydrog. Energy 2017, 42, 9500-9510. [CrossRef]

78. Urmee, T.; Md, A. Social, Cultural and Political Dimensions of off-Grid Renewable Energy Programs in Developing Countries. Renew. Energy 2016, 93, 159-167. [CrossRef]

79. Rafique, M.M.; Rehman, S. National Energy Scenario of Pakistan-Current Status, Future Alternatives, and Institutional Infrastructure: An Overview. Renew. Sustain. Energy Rev. 2017, 69, 156-167. [CrossRef]

80. Luthra, S.; Kumar, S.; Garg, D.; Haleem, A. Barriers to Renewable/Sustainable Energy Technologies Adoption: Indian Perspective. Renew. Sustain. Energy Rev. 2015, 41, 762-776. [CrossRef]

81. Akella, A.K.; Saini, R.P.; Sharma, M.P. Social, Economical and Environmental Impacts of Renewable Energy Systems. Renew. Energy 2009, 34, 390-396. [CrossRef]

82. Sooriyaarachchi, T.M.; Tsai, I.T.; El Khatib, S.; Farid, A.M.; Mezher, T. Job Creation Potentials and Skill Requirements in, PV, CSP, Wind, Water-to-Energy and Energy Efficiency Value Chains. Renew. Sustain. Energy Rev. 2015, 52, 653-668. [CrossRef]

83. Choudhary, D.; Shankar, R. An STEEP-Fuzzy AHP-TOPSIS Framework for Evaluation and Selection of Thermal Power Plant Location: A Case Study from India. Energy 2012, 42, 510-521. [CrossRef]

84. Aydin, N.Y.; Kentel, E.; Duzgun, S. GIS-Based Environmental Assessment of Wind Energy Systems for Spatial Planning: A Case Study from Western Turkey. Renew. Sustain. Energy Rev. 2010, 14, 364-373. [CrossRef]

85. Devine-Wright, P. Reconsidering Public Attitudes and Public Acceptance of Renewable Energy Technologies: A Critical Review. Architecture 2007, Working Paper. pp. 1-15. Available online: http:/ /geography.exeter.ac. uk/beyond_nimbyism/deliverables/Reconsidering_public_acceptance.pdf (accessed on 19 July 2018).

86. Neisani Samani, Z.; Karimi, M.; Alesheikh, A. A Novel Approach to Site Selection: Collaborative Multi-Criteria Decision Making through Geo-Social Network (Case Study: Public Parking). ISPRS Int. J. Geo-Inf. 2018, 7, 82. [CrossRef]

87. Malik, M.M.; Abdallah, S.; Hussain, M. Assessing Supplier Environmental Performance: Applying Analytical Hierarchical Process in the United Arab Emirates Healthcare Chain. Renew. Sustain. Energy Rev. 2016, 55, 1313-1321. [CrossRef]

(C) 2018 by the authors. Licensee MDPI, Basel, Switzerland. This article is an open access article distributed under the terms and conditions of the Creative Commons Attribution (CC BY) license (http:/ / creativecommons.org/licenses/by/4.0/). 